TE WHARE WĀNANGA O TE ŪPOKO O TE IKA A MĀUI

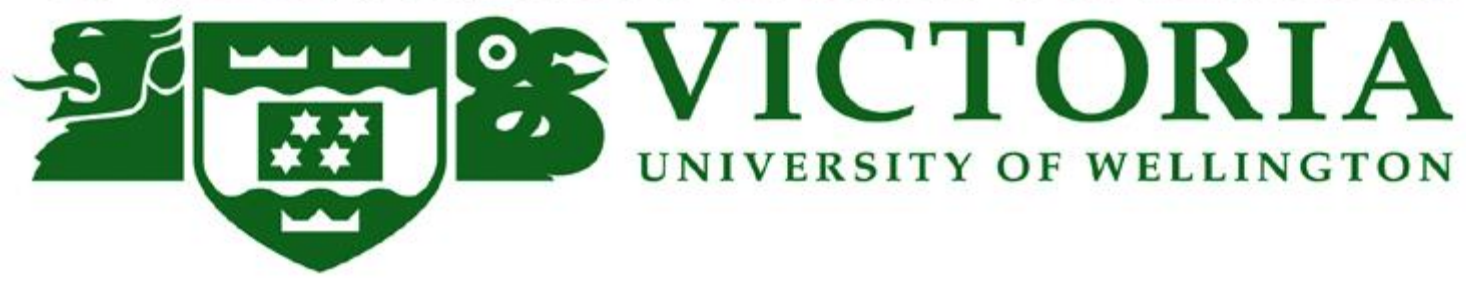

\title{
Manual to Automated Testing
}

by

\section{DAYU GUAN (Steven)}

Submitted to the School of Information Management,

Victoria Business School,

Victoria University of Wellington

In partial fulfilment of the requirements for the degree of

Master of Information Management

October 2014 


\section{Declaration}

1. I know that plagiarism is wrong. Plagiarism is to use another's work and pretend that it is one's own.

2. I have used the APA convention for citation and referencing. Each contribution to, and quotation in, this Case Study entitled Manual to Automated Testing from the work(s) of other people has been attributed, and has been cited and referenced.

3. This paper is my own work.

4. I have not allowed, and will not allow, anyone to copy my work with the intention of passing it off as his or her own work.

5. I acknowledge that copying someone else's assignment, essay or paper, or part of it, is wrong, and declare that this is my own work. 


\section{Table of Contents}

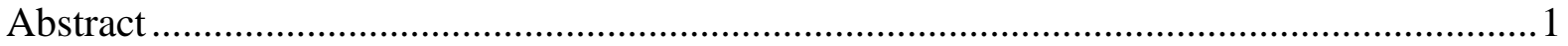

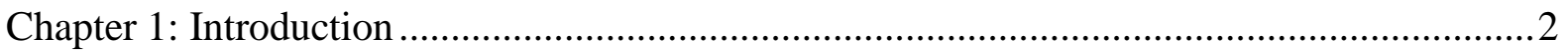

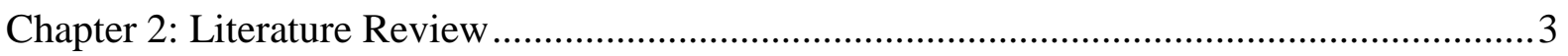

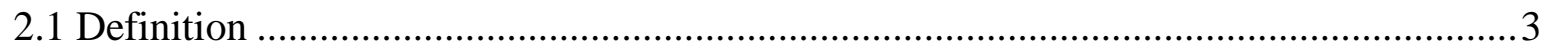

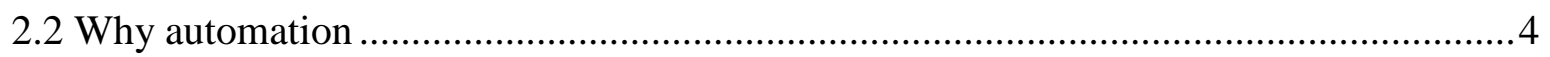

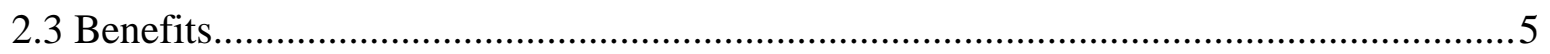

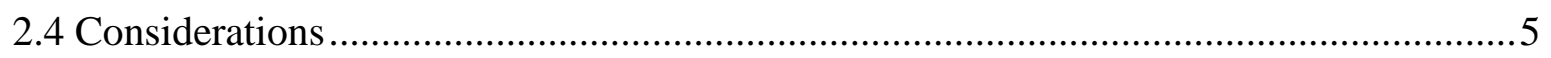

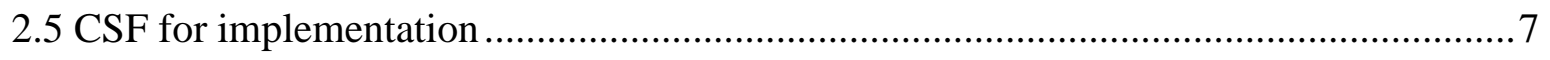

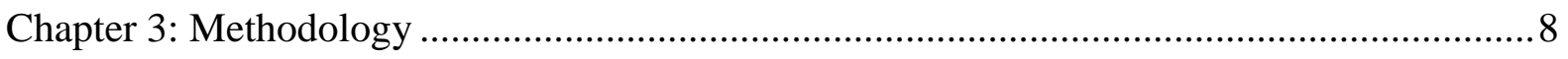

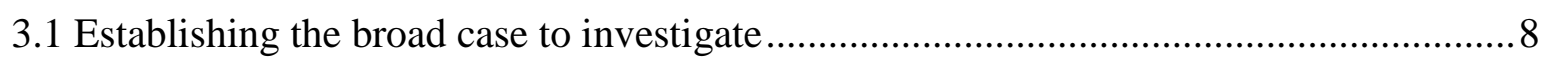

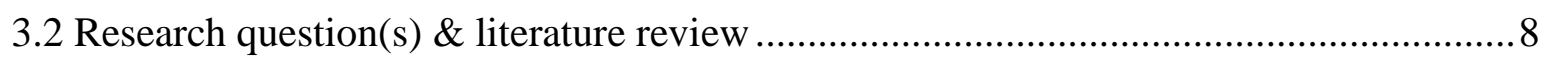

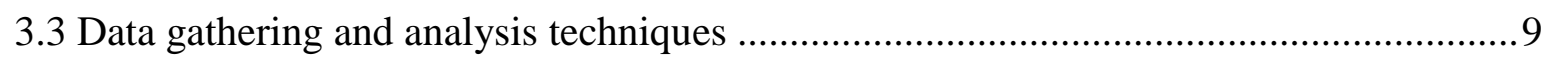

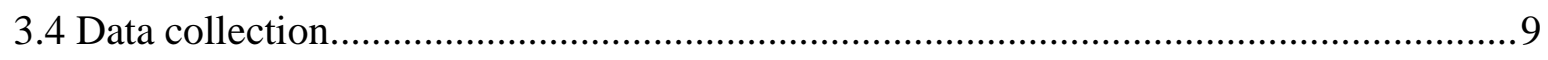

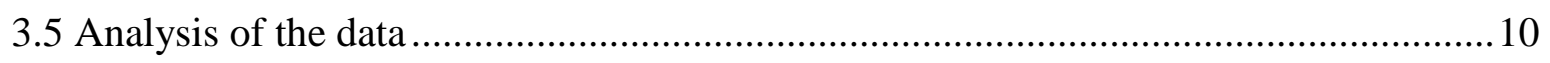

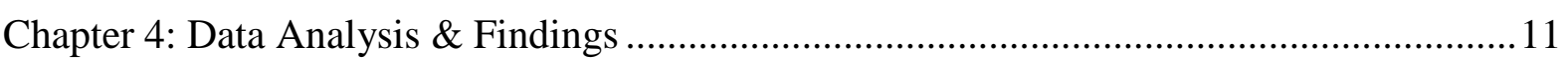

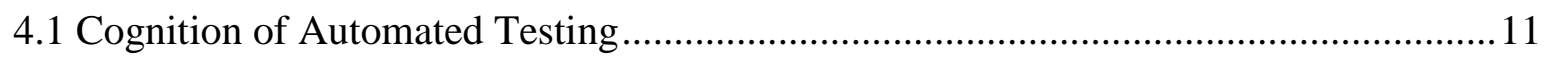

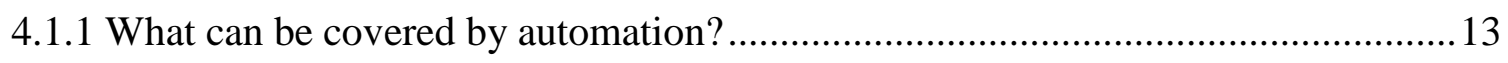

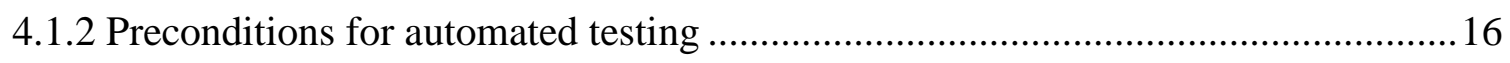

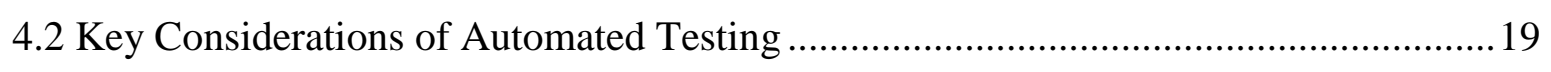

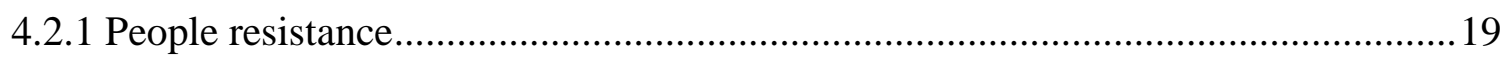

4.2.2 Can Automation drive working process? ..........................................................21

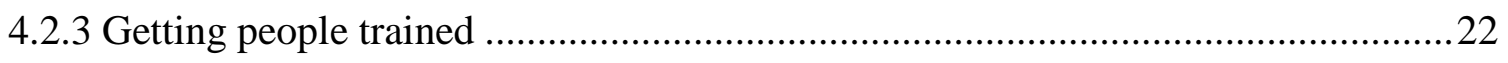

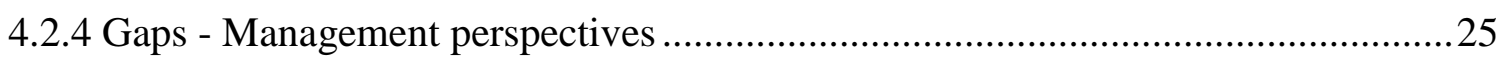

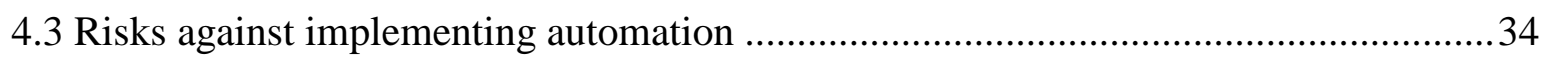

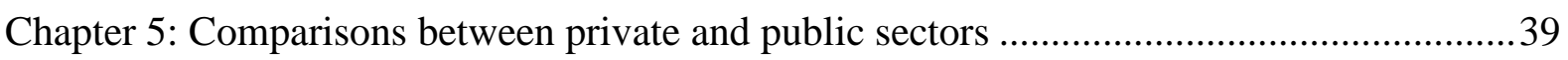

Chapter 6: Conclusions \& Recommendations .................................................................. 42

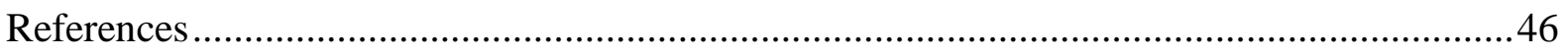

Appendix 1 - Focus Group Discussion Questions ........................................................50

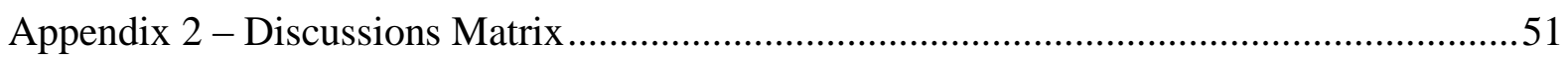




\section{Abstract}

Purpose - The purpose of this case study is to understand how two organizations view and utilise automated testing and how it relates to the literature. It outlines and discusses the key factors to be taken into consideration when setting up an automated testing, in addition to the risks involved.

Design/methodology/approach - Focus group discussions were executed to collect the data and the findings were compared with other literatures.

Findings - For cognition of automated testing, it is not only limited to its definition and benefits that may be brought into the organization, but also need to focus more on scope of application and preconditions. Aside from the key considerations such as people resistance, working process and training, some other concerns were also found from managerial perspective when adopting automated testing: (1) Cost-benefit - Return of Investment (ROI) is an effective method to analyse the investment, especially for the factors affecting the cost of investment; (2) Management support. It includes balancing between business and technology, management involvement and coordinating the relations between the departments; (3) Tool selection: Choosing the right automation tool is a very complicated process with a lot internal factors involved.

Practical implication - For an organization that doesn't have automated testing implemented yet, a pilot project can be the first option to understand its practicality and applicability based on individual organizational context.

Originality/Value - This case study can be used for an organization that interests in better introducing and implementing automated testing within the organization.

Key Words - Automated testing, Cost-benefit, Management support, Tool selection, practicality, applicability and ROI.

Paper Type - Case Study Research 


\section{Chapter 1: Introduction}

This case study provides details on building a test automation using a systematic approach in both the private and public sector. The focus of this research is in areas where automated testing hasn't been applied yet within the organization. This research can be treated as a teaching case study to guide staff on the cognition, understanding, knowledge and implementation of automated testing.

In today's business environment, project teams are expected to do more and deliver higher quality systems in less time with fewer resources. And when companies tighten their budget, software testing is often one of the first systems-development items to be done away with. IT systems that don't solve real business problems or don't perform as promised, impose a similar economic toll on business costs and results. Most software projects that fail to meet objectives or suffer significant schedule and budget slippage because defects are discovered too late. As a result, late product can lose revenue, customer, and market share.

Manual testing is still being used at both participated organizations and some concerns have been raised at a managerial level. These concerns include timing, coverage, reusability and tester's motivation and efficiency, searching for a long-term and cost-effective solution and achieving coverage against requirements.

This paper will start with literature review that will provide a starting point explaining what test automation is, what benefits could be brought into the organization, considerations that need more attention and critical success factors (CSF) to better implementing automation. A deeper analysis will then be provided on the actual situation within two organizations and then propose corresponding discussions with additional references. Also, comparisons between two focus groups are presented to show different behaviours for adoption of innovative technology. At the end of case study, some findings are summarized and also provide some suggestions on better implementing the automation. 


\section{Chapter 2: Literature Review}

Automated software testing has been considered an efficient, reliable way of ensuring software quality and improving the reliability of software compared to manual software testing. It is an important part of the Software Development Life Cycle (SDLC) because it runs through the entire software development process from requirements, system architecture, system analysis/design, coding and system implementation. There is a lot of work involved in test process management, defect process management and tester training as organizations try to deliver testing in a cost effective way. Previous research indicates that the cost and effort during testing often accounts for approximately 40-50\% of total cost and effort. Many theories have been proposed to explain best practice in automation. Although the literature covers a wide variety of such theories, this review will only focus on five themes throughout the literature reviewed. These themes are: definition of test automation, the importance of test automation, benefits that could accrue to adopting organization, considerations that need to be focused on and critical success factors (CSF) for successful implementation of test automation.

With the growing popularity of computer application within the organization, the size of software is continually increasing and the logic is increasing in complexity. Therefore, test automation is also becoming more important. During the process of testing, manual testing is a labour-intensive task with some natural characteristics including timing, intensiveness, fallibility and limitation of code covering. Unfortunately, a manual testing cannot adapt to the rapid development of organization. Therefore, it is important to consider what processes can be replaced by automated testing.

\subsection{Definition}

This review starts with the definition of test automation. As the name implies, we may assume that manual testing activities tends to be replaced by automated testing. In other words, it means that there is no human input required to generate a test. Unlike manual testing, it needs a tester to be involved at all time to interact with each of test cases, and analyses and reports the results. On the contrary, automated testing is the use of special 
software to control the execution of the tests and the comparison of actual results with expected results. Hoffman stated that software testing is automated when there is a mechanism for tester-free running of test cases (1999, p. 2). Thummalapenta et al. also described test automation is the task of creating a mechanically interpretable representation of a manual test case $(2011$, p. 1$)$. The two statements described above, clearly states that, test automation is about trying to free testers up and automate test cases. As we know, executing test cases is treated as an important procedure during the process of testing and very timeconsuming. Taken literally, test automation would seem to save time but we suppose that it will not be the only benefit from automation. Before doing that, we would like to discuss why we need test automation and the importance of automation from macro/managerial perspective.

\subsection{Why automation}

With the development of technology, IT systems within the organization are becoming increasingly more and more complex. Against each of system changes or enhancements, testing plays a vital role in delivering a product with high quality on time. There are three key aspects, speed, quality, and uncertainty in product delivery. The need of speed is practically the mantra of the information age. Late products can lose revenue, customer, and market share (Hayes, 2004, p. 4). Hayes' statement implies that the speed of new functionalities going to production will decide the degree of customer's satisfaction, as well as keeping existing customers stay and attracting further new customers. In addition, with the increasing complexity of technology as well as short product release, testing has become challenging. In terms of Software Development Life Cycle (SDLC), testing is treated as last step before going to production. However, the time being left for testing is often not good enough, especially if executed manually. How organizations are able to execute all possible test cases for complex system in short terms is a big concern. Last but not least, the cost of re-work and additional regression testing when bugs are found is costly and hard to budget for. As a result, the release of product may be affected. The increased complexity of today's softwareintensive systems means that there are a potentially indefinite number of combinations of inputs and events that result in distinct system outputs, and many of these combinations are often not covered by manual testing (Blackburn, Busser \& Nauman, 2004, p. 1). 


\subsection{Benefits}

We have pointed out above why automation is important in today's scenarios. Now it is time to discuss what benefits can be brought into the organization. There are many articles to discuss about the benefits test automation could bring into the organization. We have had an idea about automation from its definition in the beginning for the review, provided by couple of authors. Those definitions concentrate on building up a mechanism for test case automation, which means that special software will be used to run test cases via prepared scripts instead of the tester. Fewster \& Graham stated that we can run through some 20,000 scripts in three days plus the allowance of one day for contingency. The one day is to cover various unforeseen events, such as data or network, etc. not being $100 \%$ correct $(1999$, p. 346). Obviously, the speed of automated testing is definitely faster than manual and the time required for testing is reduced dramatically. Automated tests facilitate the use of coverage tools and profilers, which significantly eases an iterative refinement of test cases. This is far more difficult with manual tests. It helps to create better test cases, with a defined quality with less effort (Berner, Weber \& Keller, 2005, p. 6). Another author linked time with costs together said that manual testing involves a lot of effort, measured in person per month. Using automated testing, with special tools, this effort can be dramatically reduced and the costs related with testing can decrease (Pocatilu, 2002, p. 97). Beside timing and less effort, there are also other benefits we have to consider. As we know about one of principles of testing, exhaustive testing is impossible but high coverage is still one of expectations from tester perspective. High coverage of code (e.g. statement, branch, and path) is achieved through automation (Rafi et al., 2012, cited by Saglietti \& Pinte 2010; Tan \& Edwards, 2008; Alshraideh, 2008; Malekzadeh \& Ainon, 2010; Burnim \& Sen, 2008; Karhu et al., 2009, p. 37). Automation can reduce the cost of failure by allowing increased coverage so that errors are uncovered before they have a chance to do real damage in production (Hayes, 2004, p. 7).

\subsection{Considerations}

Test automation is able to bring lots of benefits into the organization, but it may not an easy application to be implemented within the organization. This is because the realization of changes of process must be considered throughout whole organizational structure including organization, people and technology, rather than individual changes. Test automation may seem to be a single change from manual to automation. However, it should ideally be 
considered in terms of all possible factors that may be affected by the changes. Under this review, we may ignore organizational factor because it will not be a direct factor that affects the implementation of test automation. Therefore, the factors of people and technology will be considered. From a people perspective, we should focus on how to make users accept the changes, rather than forcing it upon them. Adopting a new technology is not an easy task, but is a process of user cognition that is very time-consumed. IS research has long studied how and why individuals adopt new information technologies. Within this broad area of inquiry, there have been several streams of research. One stream of research focuses on individual acceptance of technology by using intention or usage as a dependent variable (Venkatesh et al., 2003, p. 427). From a technology perspective, we should think about whether there are some limitations towards use of automation. Most of organizations have their own in-house system that has become more and more complex after years of accumulation. The question often asked at the outset is "Can automation testing replace manual testing"? One of the views proposes that automation testing cannot replace manual testing. It is manual tasks that detect most new defects and not the automated ones (Berner, Weber \& Keller, 2005, p. 5). Other author also advised that of the bugs found during an automated testing effort, $60 \%-80 \%$ are found during development of the tests. That is, unless you create and run new test cases under the automation tool right from the start, most bugs are found during manual testing (Kaner, 1997, p. 11). These two views probably imply that automation can be used as a kind of supplemental tool, but not a full replacement of manual testing. Once automation is agreed to be a supplemental tool, other concern will come up as how does it fit in the current process? The development process that the developers follow needs to be mature enough. If the process is poor, test automation will not help (Damm, Lundberg \& Olsson, 2005, cited by Fewster \& Graham, 1999; Kaner et al., 2002, p. 13). Although this point is discussed from developer's point of view, it could still be applied to testing perspective. For development or testing, they all have their own set of procedures/standards to follow. Whenever there are any new things, the process of revaluation needs to be done. The process of test automation needs time to mature: Creating the infrastructure and tests for automation requires time, hence maturity of automation (and related benefits) requires time (Rafi et al., 2012, cited by Bashir $\&$ Banuri, 2008, p. 2). Last but not least, people with appropriate skills for automation are needed. Automation doesn't mean that the testers are "hands off" from testing. If people don't have relative skills, the training should be provided. Fecko et al., proposed five points as challenges of test automation. One of those stated as "teach testers how to write and run automated tests as a regular part of their responsibilities $(2002$, p. 3).” 


\subsection{CSF for implementation}

From the discussions above, we have covered the: (1) importance of automation; (2) benefits that automation may bring to the organization; and (3) factors that may affect the implementation of automation. In the last stage, we may need to consider how the organization would make automation better implemented within the organization. Creating an effective framework is crucial to the success of any automation effort. Dustin et al. (1999) proposed a test automation life cycle includes decision to automate test, test tool acquisition, automated testing introduction process, test planning, design and development, executing and managing of tests, test program review and assessment. Pettichord didn't provide a normal framework, but some special notes of the considerations and challenges that are particular to test automation are given as follows: (1) improve the test process; (2) define the requirements; (3) prove the concept; (4) champion product testability; (5) design for sustainability; (6) plan for deployment; (7) face the challenges of success (2001, p. 3). These seven steps can be treated as being inclusive of framework, provided by Dustin. It is important to identify what major factors need more attention and identify methods and ways to successfully implement automation testing. 


\section{Chapter 3: Methodology}

The University of Melbourne (2010) identifies eight steps in a case study research: (1) Establish the broad case to investigate; (2) Establish the research question(s); (3) Select the precise case(s) to be used; (4) Determine data gathering and analysis techniques; (5) Prepare to collect the data; (6) Collect the data; (7) Analyst the data; (8) Prepare the report. In this section all the steps above will be covered except for step 3, which was covered by the literature review previously.

\subsection{Establishing the broad case to investigate}

An email with an Expression of Interest (EOI) was sent to potential target organizations. Two organizations were selected from public and private sector testing services to participate in this research. Participants were asked to take part in one of two focus group discussion. The reason of two groups being chosen is that this research makes use of qualitative methodology as an approach that explores a phenomenon within its context using a variety of data sources. A qualitative approach allows us to explore challenges and considerations more deeply through a variety of lenses.

\subsection{Research question(s) \& literature review}

After the case study with the topic is established, a series of questions that begins with how, what and why are needed.

The literature reviews provide a good opportunity of understanding what is already known and what others have done in the area of automation through different sources like books, journals, and online discussions. This will allow us to create questions that are better suited to explore the topic. It also helped identify gaps between what has been reported and what areas might be of research interest. These gaps help in generating a set of focus groups discussion questions as a process of data collection. 


\subsection{Data gathering and analysis techniques}

The data for this research was collected using dynamic focus group discussions to collect information. A researcher guided the group based on a predetermined topic and encouraged participants to share their knowledge, skills and experiences in terms of personal point of view.

A set of focus groups discussion questions (see below) was provided to each of groups at least 2 days in advance of the discussion to allow time for preparation and clarification if needed. The questions were 10 in total, covering different areas. General questions were asked to everyone, and specific questions were also available to each of person within each of groups depending on their own role. Based on the interviewed organizations and the reviewed literature, all questions were designed around definition, benefits verification, business process, consideration, challenge and critical success factors (CSFs). The focus groups sessions were scheduled for half an hour and were held at a meeting place, agreed by both parties. The discussions were led and conducted by the researcher, and audio recording was taken of each.

1. Can you each please describe your position within the organization?

2. How would you describe the current status of manual testing?

3. What issues or problems are experienced with manual testing?

4. What is your opinion of automated testing as the best solution against problems with manual testing? Explain?

5. In terms of the current situation within your work situation, what investment would be needed to implement automated testing? What returns would you expect from the investment?

6. In your opinion, what factors need to be considered before the implementation of automated testing?

7. In your opinion, how would a process of automated testing be implemented?

8. If automated testing was implemented, where should it be applied?

9. How might automated testing affect your role?

10. Would automated testing in public sector organisations differ from that in the private sector - if any? Please explain.

\subsection{Data collection}

These steps were used in data collection: (1) Hardware: Audio recorder was borrowed and ready to be used during the focus groups discussion; (2) Participants selection: In terms of characteristics of the topic - "Manual to Automated Testing", all participants from each of 
the groups were chosen by key contacts as members of the testing and development team. They included a test analyst, senior test analyst, test lead, team manager, test delivery manager and senior developer. All of them are familiar with process of manual and engage in software testing life cycle (STLC) on a daily basis. In the meantime, they are also very interested in transition from manual to automated operation; (3) Time schedule: An invitation was sent to suitable candidates identified in both organizations inviting them to a focus group. A brief introduction, background and the purpose of interview was explained. Participating candidates was received an information sheet and participant consent form with more details. The time was set up at a suitable availability for both parties; (4) HEC approval: A Human Ethic Committee (HEC) approval was granted by University before focus group discussion started.

Each of focus groups discussion commenced with the introduction of the interviewee and researcher, the purpose of focus group discussion, explanation of the use of the data and gratitude for the participation and contribution of the interviewee.

Two scheduled focus groups discussion took place. The interviews from eight people under two groups proceeded smoothly; all of the participants were helpful in responding to the questions and providing rich, meaningful answers and discussions.

\subsection{Analysis of the data}

Interview matrix was used to do a comparison between each participants in different groups against the literature reviews being done. Based on the data we collected, the comparisons between the answers from focus groups and literature reviews were made. 


\section{Chapter 4: Data Analysis \& Findings}

Previous literature defined automated testing, the benefits that may be brought to the organization, considerations that need to be focused on and critical success factors for implementation. In order to better understand automated testing in the organization, these focus group discussion were conducted to collect data collection. Comparing the results to the literature review, there are some similarities and gaps from all participants in terms of different perspectives.

\subsection{Cognition of Automated Testing}

Dascal \& Dror stated that technological advances have been an integral part of human development throughout history. In recent decades such advances have been dramatic in that many of the new technologies have quickly penetrated into activities in the daily life of ordinary people (2005, p. 451). Automated testing has been applied in some areas for some years. However, it is still a brand-new concept for the interviewed organizations. As a new technology, cognition of automated testing is very important because it is an indispensable step for adoption within the organization. Some estimates indicate that, since the 1980s, about 50 percent of all new capital investment in organizations has been in information technology (Venkatesh et al., 2003, cited by Westland and Clark 2000, p. 426). Yet, for technologies to improve productivity, they must be accepted and used by employees in organizations (Venkatesh et al., 2003, p. 426).

The results from all focus groups found that cognition of automated testing can be categorised into two areas - what is it, what are expected benefits. Majority of respondents were base line employees while others were engaged in managerial activities. Their expectations focused on how the issues are able to be sorted using automation during the manual process, but was varied depends on different role. In general, they all have a good understanding about automation in theory and the potential benefits, as it is a process of transiting testing from people-driven behaviour to machine execution to free testers. This matches what was found in the literature. 
Lisa is a senior test analyst in private sector and has been working in testing area for long time. The issues she had from manual testing can be repetitive and time-consuming. She found that people often try to write test scripts that have already been written prior for the same thing. She expressed that:

"We are purely repeating lots of the same thing over and over again. Automated testing can speed the things up, which is good. “

She also gave four points as her expectations:

“(1) Speed; (2) Accuracy; (3) Making staff happier. It can be split into two benefits, one is that automation can make work more interesting with new tools and new roles and the other is that it can make results quicker; (4) Will be beneficial to project. Project managers or designers can script and simulate ideas upfront.

Apart from the points relative to job performance and quality of work, she also emphasized job enjoyment. We may assume that employees feel bored if they have been working with an organization for more than 5 years, with the same type of work. The employees with less interest can lead to less productivity within the organization. Employees can make or break an organization (Attar \& Sweis, 2010, cited by Deal, 2007, p. 44); they are considered valuable assets to the corporation, and the success of any company is directly linked to the satisfaction of the employees who embody that company. Job satisfaction is an important criterion for the success of an organization where it is closely associated with job turn over and life satisfaction (Attar \& Sweis, 2010, cited by Kumar, 2002, p. 44).

Lisa's colleague - Susan, who is a team manager in the same team with her, has a background of knowledge application. She has also done project management, business analyst work and testing (she joined as a test lead role) as well. She takes more responsibility on managing the whole process and coordinating and reporting. Therefore, she places more emphasis on:

“(1) Saving time: Automation can take couple of hours while manual process takes a day to complete; (2) Reporting: Reports can be produced consecutively; (3) Cost reduction: It initial 
investment costs might be expensive but long terms benefits result in greater cost saving or revenue. "

It is not hard to see that the people at the level of management pays more attention to managerial activity and long terms investment while a base line worker focuses the work on a daily basis. In fact, the purpose of exploring the benefits expectation from employees is to figure out what causes people to accept new information technology? The theory of perceived usefulness can be applied to understand how the employees within the organization is able to get better cognition. People tend to use or not use an application to the extent they believe it will help them perform their job better (Davis, 1989, p. 320). The cognition towards new technology is just how the issues being experienced can be better dealt with, but only with different view in terms of individual role. However, not all participants agree that automation will help them sort out the issue during the manual process and two themes emerged:

\subsubsection{What can be covered by automation?}

Helen is a contract test lead in the private sector for data migration project. She summarized one of the issues from manual processes as below:

"Normally, test data needs to be prepared before data migration testing starts. However, we don't know where they are placed. All of them are stored in the share drive, but there are so many links and paths to it, which are not real accessible. What we normally do is to find out the previous project as a reference, for example, six months ago to see where they are?"

She has had a training for one automation tool before, but never had a chance to work with it from end to end. She didn't think that the automated testing was the best solution against the data issue. The reason is that test data still need to be prepared regardless of whether manual or automated testing is used.

Another interviewee - Andrew from public group, who is team manager in the testing team, had the same view about data preparation. He suggested that:

"A lot of our systems are based on time-based data. For example, we are ok for tests this month, but not because of the data being changed. The tests are right, but are not able to be 
re-run because the data is not accurate for tests. We write manual tests, but we don't pay to maintain it. ",

The responses from Helen and Andrew enable us to consider what type of test activity can be covered by automation? When the other focus group question "If automated testing was implemented, where it should be applied?" was asked, we may need to think about what type of testing can be covered by automation. These two thoughts make up an overall question, as sub title is shown: "what can be covered by automation?" The majority of participants had a common point that repetitive tasks, such as regression testing, are main candidates for automation because they typically need to be executed many time. For example, Helen explained that:

"Automation is suitable for repetitive task against regression testing. It could be for some phases where small changes are required, but where we have to cover 10 different steps (repetitive steps), for example, before performing the last step. '”

Susan also stated that:

"Automation is suitable for repetitive cycle in terms of keeping system up-to-date."

However, Helen and her colleague - Lisa also had additional comments for the regression testing. Helen said that:

"Automated testing should be applied to area where the modules are kept unchanged. "And Lisa suggested that:

"Automation should be applied to regression testing, but it still depends on what you are testing. “

These two comments indicated that stability of the application or module needs to be firstly considered before automation applies. For an application or module that may be changed rapidly in the future, the automation is not necessary. This is because the corresponding 
automated scripts need to be updated once changes are applied. The cost of automated script maintenance could be very high.

Beside of regression tests, other types of testing were also discussed by some participants. Helen provided a comment on System Integration Testing (SIT) that:

"I definitely do not use automation for SIT, which is System Integration Testing. For a new system, I cannot execute automated script. We have to understand the system with architecture diagram and know where the output file goes to, for example. "

System integration testing (SIT) is a high level testing process in which the tester needs to verify all relative systems can operate in coordination with other systems. Her comment implied that the automation is not a good idea while testers are not really familiar with the whole system. If an error occurs during the running of automation, they may not understand where it come from and who they need to ask. The automation could be used for SIT, but it seems that understanding the system should be a precondition before the automation starts.

Noelle \& Lily come from an outsourcing company and work in the testing team as contractors in the private sector. They highlighted on UAT (User Acceptance Testing) that:

"UAT would be not so good for automation. Users have to give their own opinion on how usable the interface is so people are needed. Automation is not for testing user ability."

Their concerns indicated that some testing involving sensory aspects, like interface aesthetics, experience of sound and ease of use, should use manual process, rather than automation. These kinds of testing can be verified by humans, but is very hard to execute it by machine as tool doesn't have imagination and flexibility itself. Finsterwalder expressed that acceptance tests need to be repeatable and should be run at least once a day (2001, p. 114). This way, any defects that have been introduced into the application can be detected and corrected as soon as possible. However, it is difficult to automate tests that involve the GUI. To test the 
application in its entirety, tests should actually exercise the GUI of the application and verify that the shown results are correct. In order to verify these results, different attributes of the shown GUI widgets, like colour or text, must be examined. But automated control and inspection of GUI widgets is not easily possible.

The discussions above are analysed in terms of testing types. Functional and non-functional testing are also mentioned. Some participants recommended that automation is for functional testing while others suggested that automation should be applied to non-functional testing, like performance, load and stress testing. Coy, who is a contract test analyst in the private sector, has been involved in quite a few different places for performance and load testing before join the current position, explained:

"We cannot have 10 thousand people log on at once, but we can simulate it by automation."

Borland proposed definition of functional testing and also gave a reason why automating functional testing is needed. Functional testing, or black box testing, is a Quality Assurance (QA) process used to verify that an application's end-user functionality (i.e., the ability to log in, complete a transaction, etc.) works accurately, reliably, predictably and securely (2012, p. 2). While manual testing is appropriate in some cases, it is a time-consuming and tedious process that is inefficient and conflicts with today's shorter application development cycles. For non-functional testing, end users should pay attention to "how well" or with what quality the system should carry out its function. Just like Coy mentioned, there is no point in letting 10 thousand people log in at the same time to test whether the webserver or window based application can withstand the load. Instead, automation tools can simulate it in a short period. However, if the GUI is treated as part of non-functional testing, it will be untestable, as referenced from Finsterwalder.

\subsubsection{Preconditions for automated testing}


When the benefits expectations were discussed previously, some participants mentioned automation is not the best solution against the issues they experienced, but it could be used with some conditions. Noelle summarized the issues as:

“(1) Inconsistent mapping document: For example, the information they provide doesn't match with the table structure; (2) Location: The applications are located in Melbourne, Australia and developers are over there. All users are in Auckland. Sometime, other downstream systems are located in Sydney, Australia. The project is located in four different places. Communication between the four places is not ideal; (3) Team structure: There are lots of application knowledge you need to understand. However, there is lack of permanent staff and it's hard to get people who are available. The proportion between contractor and permanent staff is 20:3. “

Also, they further explained that the issues need to be sorted out first to make automation easier. In other words, the automation will be an enabler to solve those issues.

When Susan was asked by the question "What issues or problems are experienced within manual testing and what is your opinion of automated testing as the best solution against problems with manual testing", she described:

"The process is not well-known and well-established within the company. I don't think that automation is a good solution and all depend on what type of testing you could use automation or not. “

Although Lisa agreed that the automation is the best solution for repetitive task, but she also mentioned that:

"A lot of work I do is project based for specific change so I don't always get overly repetitive work. This depends on how much you have to go run the same thing. And majority of the team are contractors. We all bring our own ideas on testing methodology. The organization has no one single way to follow. “

Andrew is a team manager and delivery of project is one of his responsibilities. He complained that: 
"We do project work and other parts of business does production support. Sometime, functions are changed as the business requires, which causes our tests failed. Also, we have lots of stuff vendor developed, around 80/20. Communications is always our problem because we get requirements here and then go out and pick up when we test. In terms of this, we test on a risk-based approach. We work with the business to find out what is good or bad for them if it goes to production. "

Based on the interviews, some concerns can be listed as preconditions before automation starts.

Firstly, communication issue was raised by Noelle and Andrew. Noelle's comment described that communication issue was caused by distributed project resources. The role of communication in project is very important. If project team is not in the same place, it will not only affect the progress of effective communication, but also influence the realization of team goals. Therefore, centralizing project resources is a consideration. Decentralization would be associated with efficiency advantages stemming from improved information processing and reduced scope of managerial opportunism. However, other scholars have argued that such advantages of decentralization may be outweighed by the inability to achieve economies of scale or scope in R\&D. Centralization of certain functions may enable a firm to exploit economies of scale and scope in administration (Argyres \& Silverman, 2004, cited by Galbraith, 1977; Daft, 1989, p. 932 - 933). In addition, Andrew's comment focused on poor communication caused by excess outsourcing. If communication between the development team and test team is not good enough, end users will not get the expected results. Just like Andrew mentioned, they can only use risk-based approach. An outsourced vendor may be catering to the expertise-needs of multiple organizations at a time. In such situations vendors may lack complete focus on your organization's tasks (Flatworld Solutions, 2014, The Disadvantages of Outsourcing section, para. 4).

Second, both Noelle and Lisa, who are working in the same team, complained that there are many contractors working there and it's hard to get people when needed. Generally speaking, the mobility of the contractor is relatively larger than permanent staff. They often work in one place for couple of months or up to one year and then jump to another one. As a result, it is impossible to have a standard and formal testing process to follow within the team. On the 
other hand, it is not worthwhile for an organisation to train a contractor who will be leaving in a certain months.

Third, doing a right assessment in terms of the type of work is required, for example, project based or Business as Usual (BAU) work. Lisa always does project-based work and is not often involved in regression testing. This means that the requirements of software change frequently. For automated testing, the stability of the test script will decide how much the cost of maintenance for automation will be. If the requirements of software are updated too often, test personnel need to upgrade test cases and relevant automated scripts. Yet,

maintaining script itself is just a process of development, which is time consuming and costly. Therefore, introducing of automated testing fails if the cost of maintenance is higher than the cost being saved from automation.

\subsection{Key Considerations of Automated Testing}

The fact is no automation exists within the testing team for the interviewed organizations. Although they have a good understanding of automation knowledge, some key considerations are still needed to be analysed and explored before implementation, from both technical, managerial and organizational perspectives. Dance proposed that people, process, and technology are essential pillars for effective innovation in any organization/team and each must be addressed separately and integrated collectively to assure innovative results (2008, para. 1). In this section, we would like to deeply explore it based on both reviewed literature and participant's feedback.

\subsubsection{People resistance}

Referring back to previous literature review, the considerations for automation were elaborated from perspectives of people and technology. All interviewees were asked all of the relevant questions from this section, and the answers from some of them are quite matched with the literature said. Noelle was concerned that people may show their resistance for use of new technology. The reasons why they resist are varied with different views, which include ease of use, the influence of the workflow and loss of control. During the interview, an additional question was asked by the researcher "do people fear being made redundant?" This point has been listed as one of top 12 reasons why people resist change by Rick. He identified that lack of competence is a fear people will seldom admit. But sometimes, change 
in organizations necessitates changes in skills, and some people will feel that they won't be able to make the transition very well (Rick, 2011, Top 12 typical reasons for resistance to change section, para. 3). For the automated testing, all participants gave a similar answer that losing the job is no need to be worried. Some typical answers are listed below:

Lisa is a contract test analyst and she said:

"We only have two permanent staff, and not a big enough organization to lose key accounts. People are still needed to write/maintain test script, and analyse the requirements. People being replaced by automation could happen in a big size organization. I am contractor and don't think that it will affect me. If I were permanent staff, I am pretty confident to be involved in and expected to up-skill, train and learn."

Coy is also a contract test analyst doing manual testing and she doesn't care about whether automation affects her. However, she gave an assumption that if she was permanent staff, she could learn new skills. During the interview, a further question was asked of her, "Will automation replace manual testing in the next 5-10 years?" She said:

"Automation will not do everything by itself. If something fails, someone needs to look at it. Automation can do what I should call 'bulk' or 'donkey' work, but people are always needed to look at it. The other thing is that the organization has increasing number of applications and people can do things themselves (whether it's on the tablet, whether it's on the phone and whether it's on the computer). These are all visual things. Automation doesn't always get it right. Automation can search for the things it expects to see, but it cannot search for problems outside its programmed instructions."

Technically speaking, their comments suggest that automated testing cannot replace manual testing. It can only enhance or supplement manual testing, but will never replace humaninvolved activity to conduct testing.

Susan plays a managerial role within the testing team. She is very open to changes and said that new stuff can interest employees and also make things happen in a better way. In addition, the world is changing constantly and the employees just need to adapt it and learn new skills. Last but not least, the automation can save time for them obviously. 
Three things were mentioned in terms of technical perspective from reviewed literature. The first has been discussed already: "manual testing cannot be replaced by automation". The other two things are how automation fits in the current manual process and what training should be provided for employees. Firstly, a doubt between current testing process and automation was proposed by Lisa:

"Does the subject material allow for it? Can something be automated?"

And Susan, as a team manager, stated that:

"We need to actually determine what process will benefit from automation. I am pretty sure that some processes we had are easily automated. But that still needs to be worked out and determine how we do the things faster and more efficiently in the future. I think that it is a good opportunity to learn and develop in the organization."

Lisa doubted whether the current process can fit automation while Susan reckoned that it is a good opportunity to develop the working process. In an ideal world, new technology can just fit in the current working process. However, the reality always shows the opposite of we expect. As a result, the current working process has to be reassessed to see whether it fits the new technology or it needs to be improved in advance. Combining the reviewed literature and participant's responses, it is necessary to focus on "Can automation drive working process?"

\subsubsection{Can Automation drive working process?}

When new technologies are broached in organization, people usually think of changes in proficiency, control and potential side-effect. These concerns have been mentioned previously as some of reasons why people resist the change. Technologically, it also has an impact on the way under which work is achieved - i.e. working/business processes. Presumably, the organization has decided to make use of automation as a supplement tool for testing, people and working processes are affected more or less. Therefore, we may say that automation can drive the processes, but we need to pay attention to two things. First we need to include people and secondly we need to assess the impact of potential changes. Walton \& McKersie find that new technologies are often essential to the effort of enterprises to become more competitive. How the technology is introduced, in particular, and how labour- 
management issues are handled, will strongly influence whether the new technology makes its potential contribution $(1988$, p. 1). These two authors identified the importance of people management during changes. In other words, employees' negative emotions or views may influence the actual effect of the new technology. In addition, WORKSOFT indicated that with IT delivering such key benefits, organizations must be able to rely on their enterprise solutions without fail. Having systems break or business processes be disrupted because of the rapid pace of change can be very costly both in terms of lost revenue as well as lost customers (2011, p. 3). Driving processes doesn't mean to succeed in implementing automation while having other parts fail. It is essential to have a reasonable way to assess the impact surrounding the changes.

\subsubsection{Getting people trained}

Under the section of literature review, the necessity of training has been mentioned. During the group discussion, most of the interviewees showed the recognition of the importance of training. When the question "what investment would be needed to implement automated testing? And what factors need to be considered before the implementation of automated testing?" was asked, they highlighted that training should be treated as one of important considerations or as part of investments for automation. Helen explained that:

"There is no automation tool in the testing team, so the first step should make the tool initiated and get it installed on the machine. Once the tool is installed, we will understand further what we really need. Also, there is no point to get licences to install on every PC. Instead, just choose someone who really wants to grow his or her career path and have that person champions the product."

Her comments emphasized that a tool should be considered as the first investment, followed by proper training to people. But local training should perform first from an economic point of view.

Lisa also agreed as training is necessary and able to provide a good opportunity to expand the knowledge base of staff. In addition, she further underlined that: 
“Getting permanent staff trained is a must, but I don't like that people get training and leave. People with new knowledge should stay and pass information to others (knowledge management). "

Allan \& Andrew come from public sector and stated that education is very important. In the meantime, Andrew, who is a team manager, also added two additional points as:

“(1) If education is provided, people who don't know how to do it are not afraid; (2) We need to keep changing, and technology needs to be attempted by someone in the right level. This is good thing and everyone will be buy-in to it. "

Andrew's positions are obviously from a human resource perspective, and also from the overall consideration. First, proper training can make employees more confident and reduce their worries about being abandoned by the team or organization. On the other hand, people with knowledge in the right level can share their experiences and knowledge to others, in order to balance skills within the team to make job easier and more efficient and effective. Frost advised that a development program brings all employees to a higher level so they will all have similar skills and knowledge. This helps reduce any weak links within the company who rely heavily on others to complete basic work tasks (2014, Addressing Weaknesses section, para, 1).

From the discussions above, it seems that proper and timely training plays a pivotal role for implementing automation. However, two additional concerns can be extracted from Helen \& Lisa's response. These two concerns make the training more economic and effective. (1) Getting permanent staff trained: Both Lisa and Helen are contractors in private sector and they fully understand the difference between contractor and permanent staff. In the interviewed organizations, the proportion between contractor and permanent staff is $20: 3$. They believe that there is no point in training contractor who will be leaving in a short time. Therefore, the organization has to re-consider the team balance before beginning an automation; (2) Get acceptance of new tools: Just as Helen suggested, getting an automation tool installed on a trial PC and training a person or a small group of people first is a better idea. The reason being that new technology for the organization has a lot of uncertainties such as people resistance, cultural differences and adjustment of working processes. Technologies that are new to an organization present a number of issues simply because they 
are new (Tost, 2010, p. 1). Tost also provided a sample of technology lifecycle (Table 1) below (p. 2 - 3):

\begin{tabular}{|c|l|}
\hline Stage & \multicolumn{1}{|c|}{ Description } \\
\hline Introduced & $\begin{array}{l}\text { A technology or product is brought into an } \\
\text { organization for the first time. This is when various } \\
\text { groups get to take a first look at the technology, often } \\
\text { testing its use in the form of a proof of concept. }\end{array}$ \\
\hline Planned & $\begin{array}{l}\text { Initial planning has been conducted for the technology } \\
\text { to go into production in support of a business solution, } \\
\text { which will act as a pilot. The planning activities } \\
\text { include operational aspects. }\end{array}$ \\
\hline Deployed & $\begin{array}{l}\text { The technology is in production, in a limited fashion, } \\
\text { supporting only one or two business solutions. }\end{array}$ \\
\hline Mature & $\begin{array}{l}\text { The technology has reached a high degree of maturity. } \\
\text { This includes organizational capabilities, refined } \\
\text { processes for both development and operational } \\
\text { support. Known best practices have been applied. }\end{array}$ \\
\hline Retired & $\begin{array}{l}\text { No new solutions can be deployed on top of the } \\
\text { technology. Existing solutions are migrated over time, } \\
\text { if possible. }\end{array}$ \\
\hline
\end{tabular}

\section{Table 1: Sample Technology Lifecycle}

It is clear to see that the first step shown on the table identifies that having a certain group to test technology's use is an indispensable part. During trialling if something fails or we find something that is not easy to handle, we still have time space to roll back. This is far better than bringing all things on and rolling all things back. Therefore, local training can reduce the investment risk. Presumably, if the trial version was successful, Lisa's suggestion could be used. She suggested that people with knowledge can stay and share useful information to others. From an economic point of view, it can help the organization save the cost of training. From knowledge management perspective, it can be also treated as an effective learning channel, even can be an influential view of technology adoption. A scholar - Rogers proposed a model known as Diffusion of Innovation (DOI). Diffusion is the process by which (1) an innovation; (2) is communicated through certain channels; (3) over time; (4) among the members of a social system (Rogers, 1962, p. 5). 
Now that we have discussed the similarities, with the reviewed literature. We still have to figure out the gaps between the literature and the participant's responses. The questions with respect to key considerations were answered through the lens of individual roles; some participants focused on the managerial angle, while others concentrated more on technical perspective. These gaps can be summarized into several perspectives:

\subsubsection{Gaps - Management perspectives}

\subsubsection{Cost-benefit analysis}

In the process of the literature review, there is a very important factor we seem to have been ignored, which is cost. However, the consideration of the cost was emphasized during the group discussions, regardless of their individual role. When the question "what factors need to be considered before the implementation of automated testing" was asked to participants, the majority of them put cost as the first consideration. At the same time, they also suggested some potential considerations relative to the cost. Helen said:

"People feel that what the benefits are in the next two years if they invest $500 \mathrm{~K}$ on automation for example. I reckon that the organization needs to do deep analysis on costbenefits. The duration of the project is a consideration for costing when doing investment. You don't want to invest so much money and to deliver a project which is only for three months. If I invested so much in QTP, I want benefits that last two years not only for three months. This is all about how long I am going to use that product for. Like online banking, mobile banking. You always use those and it never goes out of the place. Some other applications are minor and not often used. "

Coy stated that:

"If you make changes, you have to make sure they cooperate with the automation script."

Noelle explained that:

"The Project team will own the automation and should have a plan to make sure we know what we want to achieve from automation." 
Andrew suggested that:

"We need people engaged. We need to make sure the processes are actually adaptable for automation and get the right technology platform."

According to the answers above, they highlighted the problems that should be considered for cost analysis, and can be categorized into five factors:

1. Type of project and cycle: For one-off project or a project with a short development cycle, it is not worthwhile to invest in automation. This is because we spend too much time and effort to build the test scripts, but cannot reuse it.

2. Continuity of the project: If the project is continuous, there will be a lot of places where automation can be reusable.

3. Development planning for the project: It includes the times of regression testing, where to automate, where not to automate and what can be achieved.

4. Maintenance workload: Whether or not the code can remain relatively stable for a long time or functionalities will evolve.

5. Complexity: Whether or not automation is easy to be implemented, including all relative environmental factors surrounding the automation.

In order to better manager and invest in automation, we need to often determine whether the test automation can improve the efficiency and the whole benefits. Compared with the manual tests, the maximum value of the test automation is the economic scale for each test run. The calculation method of the test automation is needed to understand how much we spent on and how much can be saved from investments? The return on investment (ROI) is usually computed as the benefits derived divided by the investments made for a given thing. If organizations are starting a fresh project, they might compute the value of testing and divide by the cost of the testing to compute the return (Hoffman, 1999). A formula is given by Kelly (2011) to calculate a ROI for automation as:

\section{ROI=Benefit/Cost}

Kelly also explained that traditionally the costs used are the costs for automation (hardware, software and licenses, training, time to produce scripts, etc...). The benefits are calculated by 
looking out over a time interval at the savings automated testing offers over manual testing (reduced time to execute tests, ability to test 24 hrs. a day, etc...) (2011, p. 1). From this formula, we can see that the investment cost is very important factor, which will decide the value of ROI. We assume:

Benefit (Cost of manual testing - Cost of automated testing) is invariant so the smaller the cost of investment, the greater the return of investment, vice versa.

Hoffman (1999) proposed 10 samples of fixed automation costs. In the following, we compared those samples, with the responses from all participants to figure out similarities and discrepancies: 


\begin{tabular}{|c|c|c|c|c|c|c|c|}
\hline $\begin{array}{l}\text { Group } \\
\text { Discussions }\end{array}$ & & & e Se & & & Public & \\
\hline $\begin{array}{l}\text { Samples } \\
\text { (Hoffman, } \\
\text { 1999, p. 5) }\end{array}$ & P1 & P2 & P3 & P4 \& P5 & P6 & P1 & $\mathbf{P 2}$ \\
\hline $\begin{array}{ll}\text { Hardware } & \\
\text { (additional or } \\
\text { upgrades } & \text { to } \\
\text { existing) } & \end{array}$ & & & & & & $\begin{array}{ll}\text { - } & \text { Integration } \\
\text { server } \\
\text { - } & \text { Other } \\
\text { infrastructure } \\
\text { to support } \\
\text { automation } \\
\text { tool }\end{array}$ & \\
\hline $\begin{array}{l}\text { Test ware } \\
\text { software licenses }\end{array}$ & & & & & & & \\
\hline
\end{tabular}




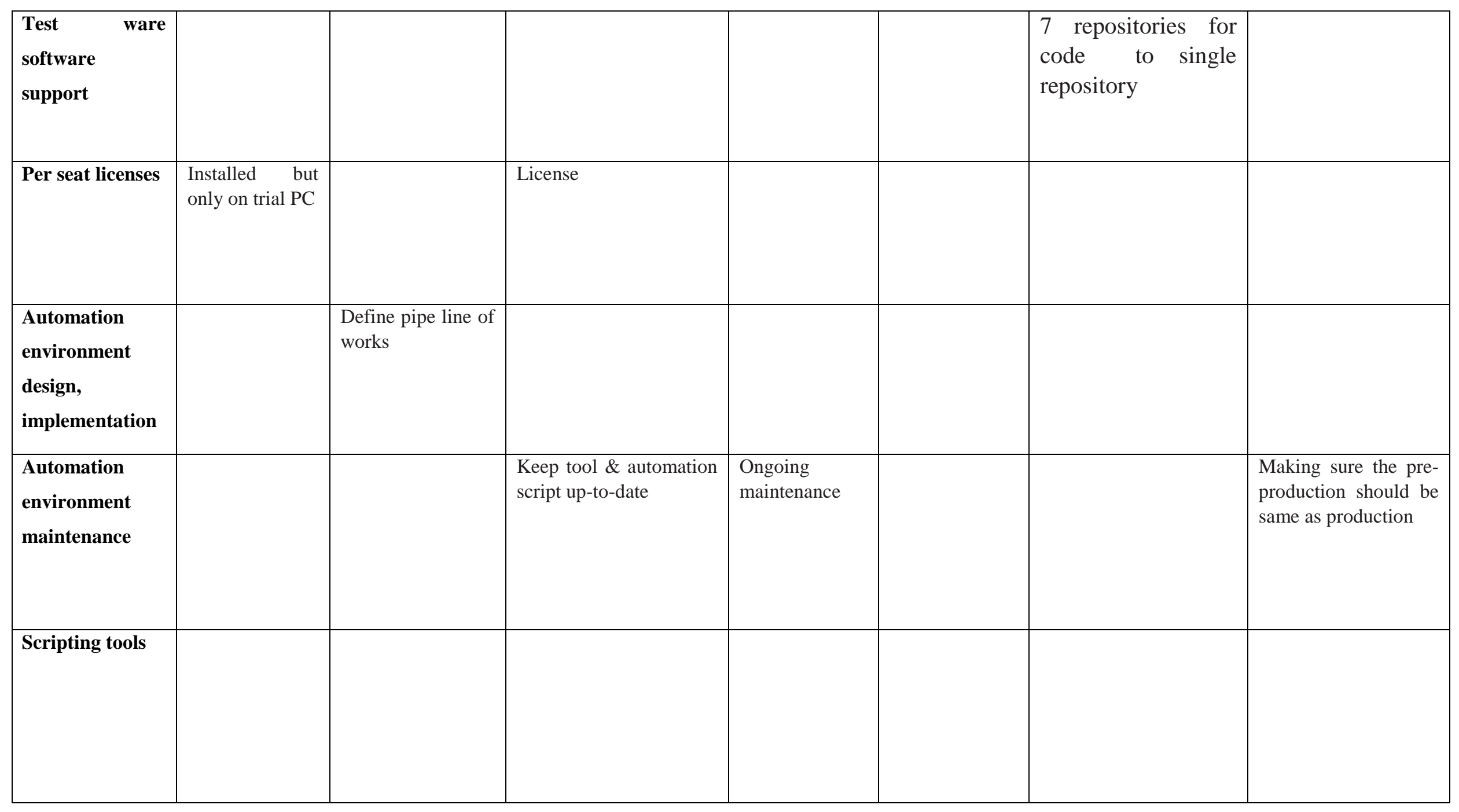




\begin{tabular}{|c|c|c|c|c|c|c|c|}
\hline $\begin{array}{l}\text { Tool and } \\
\text { environment } \\
\text { licenses }\end{array}$ & & & & & & $\begin{array}{l}\text { Making sure tool can } \\
\text { talk to outside }\end{array}$ & \\
\hline Tool training & & $\begin{array}{l}\text { Training for } \\
\text { permanent staff }\end{array}$ & & & & $\begin{array}{ll}- & \text { Tool learning } \\
\text { for different } \\
\text { type of testing } \\
-\quad \text { How to write } \\
\text { automation } \\
\text { script }\end{array}$ & Tool training \\
\hline $\begin{array}{l}\text { Tool } \\
\text { introduction } \\
\text { and ramp up }\end{array}$ & $\begin{array}{l}\text { Tool initialled } \\
\text { and get it } \\
\text { installed }\end{array}$ & $\begin{array}{ll}- & \text { Tool } \\
- & \text { Share } \\
\text { informati } \\
\text { on to } \\
\text { others }\end{array}$ & $\begin{array}{ll}- & \text { Tool } \\
- & \text { Knowledge } \\
& \text { management }\end{array}$ & Tool & Tool & $\begin{array}{l}\text { Get right technology to } \\
\text { run the things }\end{array}$ & Tool \\
\hline
\end{tabular}

Table 2: Comparisons between Hoffman's examples and Participant's views

As the table 2 shows, the responses from all participants covered majority of examples that come from Hoffman. People from both private and public sectors recognized the investment cost of automation. In fact, automated testing needs a lot of involvements in script development and debugging in the early stage. But less people are needed for most of the testing work later. However, manual testing requires some human to design and perform the test, but you don't need to buy tools and other related hardware and software. In general, automated testing involves higher upfront costs for a project while providing reduced execution costs down the road. Performing return on investment (ROI) analysis on each automation project will determine a simple approximation of cost, will help determine upfront what types of automation you want for the project, what tools will be required, and what level of skill will be required for the testing resources for the project. Not only does ROI serve as a justification for effort, but also a necessary piece of the planning process for the project (Kelly, 2011, p. 1). Last but not least, the contents in table 2 are only examples and not limited to any individual team or organization. How much will be spent on 
automation should depend on organization or team's actual situation like budget, existing infrastructure, timing, people, educational background and etc.

\subsubsection{Management support}

\section{Who is a driver?}

There were some indications of unclear business strategy and technology. Lisa explained that:

"I am working with a funny organization because the business tells technology what we need to do or not. Technology is just quite reactive and they don't say that we can do this and will do it. We have a project manager, that's a business project manager, not a technology project manager. They haven't really embraced technology or solutions we provided.

Lisa's concern may motivate us to think about who drives who between business and technology within the organization? Generally speaking, business needs to set up a goal based on its culture, background and structure and implement it using different resources within the organization. Technology, as part of resources, plays a vital role in completion of business' goal and sustainable development. Once one of parties is restricted by others, business development is not balanced. Business always wants to build up a complete plan to cater for business 'goal. However, some requirements are not feasible from technological point of view. On the contrary, if technology drives business, business may be more focused on innovation, rather than key requirements. Although breakthrough innovation is transformational, it's often the build-up of incremental but continuous innovation around existing technologies and business models that can transform the way a company does business. In 2012, 69 percent of CEOs reported that they would be changing the company's overall innovation portfolio in new products and services within existing business models (PricewaterhouseCoopers, 2012, p. 2). In a perfect world, they should restrict each other, and also be complementary to each other. Restricting others can balance their aspirations while complementing can provide more spaces to improve themselves. Keyes-Pearce proposed a definition of linkage between business plans and information system strategy. The overall definition of linkage is "the stage in which the set of IT and business mission, objectives and plans are of high quality and complementary" together with being "well understood by IS and business executives in the organization". There is variation in the use of terminology by other researchers, with "linkage" and "alignment" apparently similar (1997, p. 635). Therefore, 
collaboration of business and information technology will be the key factor for achieving business goal.

\section{Management involvement}

Lisa was asked a further question: "is there any Chief Information Officer (CIO) to take responsibility on investment?" She answered that they have a CIO in Auckland, but she doesn't know what he or she is doing and even doesn't know who he or she is? For a relatively large investment of information technology like automation, someone needs to take responsibility. This role is not only responsible for technology, but also the management and decision making of technology investment. Most importantly, it serves as a role of coordination between business and information technology. Kettinger et al. described the CIOs not only led the IT organization in delivering reliable and cost-effective IT services to support the company's domestic growth and international expansion, but also used their business insights to act as key leaders in improving the information culture in support of business process improvements and post-merger integration (2011, p. 161). Basu et al. propose that Strategic information systems planning (SISP) is an important management function. It can help an organization use information technology (IT) more competitively, identify new, higher payback IT applications, and better forecast IT resource requirements (2001, p. 513). Senior management involvement in SISP means that a top executive champions it (Basu et al., 2001, cited by Newman \& Sabherwal, 1996, p. 515). And also has been shown to lead to effective SISP (Basu et al., 2001, cited by Cerpa \& Verner, 1998; Earl, 1993; Schuman \& Rohrbaugh, 1991, p. 515).

\section{Buy-in}

During the group discussions, some participants for private sector stated that buy-in from the organization is another concern. This is because automation is a financially large investment. Buy-in is acceptance of and willingness to actively support and participate in something from interested or affected parties. On the surface, the automation seems to be only existing within the testing team. But it definitely needs to be linked with other business units to complete certain task. Therefore, internal effective communication and coordination is the key to enterprise development. Andrew who works with public sector described that: 
"There are lots of bureaucracy to get approval to do the stuff. That's less freedom because we are scrutinized by the public. We cannot do a thing until the CEO decides that it is good enough to be scrutinized by 'spending committees'. Some of them may ask questions about spending why you spend this or that. Unlike private sector, they are not driven by profit."

In either the private or public sector, the interviews indicated there is a lot of "enterprise disease", especially for large-scale enterprise with a long history. They include the high wall barriers between departments, long-standing thoughts, officialism, and contradictions between people. To fix these issues, the format of communication and coordination should not only be based on the business. Instead, it should also focus on a social basis in order to build up stronger interdepartmental relationship. The information which is exchanged in the business relationship inevitably involves interaction and social activity. The parties get to know each other as they interact (Lindh, 2006, cited by Ford et al., 1986; Turnbull et al., 1996, p. 42). The social interaction reduces uncertainty, and lets the parties find out that they can rely on each other (Lindh, 2006, cited by Granovetter, 1985, p. 42).

\subsubsection{Tool selection}

Not much about tool sections was mentioned until the group discussed privacy \& security:

Lily from private sector told us:

"The data in NZ cannot go overseas or be stored overseas. Therefore, we have to make sure the tool we use has to be hosted in NZ. This is a powerful restriction when you choose tool for automation.

Also Andrew from public sector mentioned that:

"We need to care about where the data can sit because the data is not for us and it belongs to citizens within New Zealand." 
In general, the application of test tools can improve the quality of testing and test efficiency. However, not all of the tools are suitable for us when we choose and use them. In the meantime, even if we have testing tools, but that doesn't mean it can play a role. Therefore, we must select tools according to the actual situation of the organization, in order to add the most value to it. Poston \& Sexton highlighted that in these tough economic times, software-development managers are pushing to get more and better testing done faster. Most recognize that automated testing tools facilitate higher quality and more productive testing, but acquiring such tools is often quite complicated (1992, p. 33).

\subsection{Risks against implementing automation}

We have respectively discussed employees' perception of test automation, and some key considerations in terms of the literature and actual situations in two different organizations. In the last section of the literature review, we referred to research about the critical success factors for automation. Based on this. We also proposed the same during the group discussion and the responses from participants look similar. This is shown in table 3 below:

\begin{tabular}{|l|c|c|c|c|c|c|}
\hline \multirow{2}{*}{$\begin{array}{l}\text { Group } \\
\text { Discussion }\end{array}$} & \multicolumn{5}{|c|}{ Private Sector } & Public Sector \\
\cline { 2 - 6 } & P1 & P2 & P3 & P4 \& P5 & P6 & P1 \& P2 \\
Literature & Dustin)
\end{tabular}




\begin{tabular}{|c|c|c|c|c|c|}
\hline $\begin{array}{l}\text { Decision to } \\
\text { automate test }\end{array}$ & $\begin{array}{l}\text { Once getting } \\
\text { approval from } \\
\text { manager to use } \\
\text { automation, } \\
\text { preparing and } \\
\text { analysing is a } \\
\text { major phase }\end{array}$ & $\begin{array}{l}\text { Analyse to see } \\
\text { whether the tool } \\
\text { fits for the current } \\
\text { process }\end{array}$ & $\begin{array}{l}\text { Business } \\
\text { process } \\
\text { analysis }\end{array}$ & $\begin{array}{l}\text { Do analysis about } \\
\text { whether automation } \\
\text { suits our area, } \\
\text { followed by the } \\
\text { decision. }\end{array}$ & Pilot project and then do analysis \\
\hline $\begin{array}{ll}\text { Test } & \text { tool } \\
\text { acquisition } & \end{array}$ & & $\begin{array}{l}\text { Decide what tool } \\
\text { can be used }\end{array}$ & $\begin{array}{l}\text { What tool to } \\
\text { be decided }\end{array}$ & $\begin{array}{l}\text { Choose the tool and } \\
\text { make a trial version }\end{array}$ & \\
\hline $\begin{array}{l}\text { Automated } \\
\text { testing } \\
\text { introduction } \\
\text { process }\end{array}$ & $\begin{array}{l}\text { Get people } \\
\text { internally or from } \\
\text { outside }\end{array}$ & 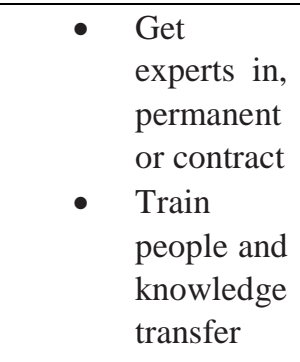 & & Hire technical person & \\
\hline Test planning & $\begin{array}{l}\text { Provide a plan } \\
\text { about how we are } \\
\text { going to do }\end{array}$ & & $\begin{array}{l}\text { Where they } \\
\text { need to go to } \\
\text { implement } \\
\text { automation }\end{array}$ & 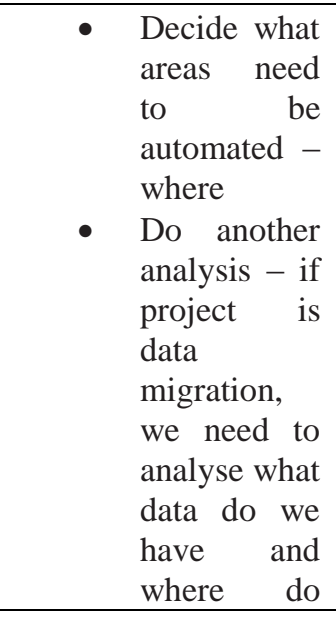 & \\
\hline
\end{tabular}




\begin{tabular}{|c|c|c|c|}
\hline & & $\begin{array}{l}\text { they come } \\
\text { from and } \\
\text { what's the } \\
\text { best solution } \\
\text { to be } \\
\text { automated }\end{array}$ & \\
\hline $\begin{array}{l}\text { Design and } \\
\text { development }\end{array}$ & & $\begin{array}{l}\text { Write/design } \\
\text { automation script }\end{array}$ & \\
\hline $\begin{array}{l}\text { Executing and } \\
\text { managing } \\
\text { tests }\end{array}$ & $\begin{array}{l}\text { Allocate r the } \\
\text { automation task } \\
\text { into two groups, } \\
\text { one is to write } \\
\text { script and other is } \\
\text { to run it }\end{array}$ & $\begin{array}{l}\text { Maintain it. The } \\
\text { knowledge of the } \\
\text { scripts about what } \\
\text { have been done by } \\
\text { automation need to } \\
\text { be maintained. } \\
\text { Someone needs to } \\
\text { keep that skills. }\end{array}$ & Moving the automation out of the team \\
\hline $\begin{array}{l}\text { Test program } \\
\text { review and } \\
\text { assessment }\end{array}$ & & Lessons learnt & \\
\hline
\end{tabular}

Table 3: Comparisons between literature and participant's feedback 
Based on the table 3 shows, it is clearly that participants recognized the basic processes for implementing automation. Yet, these steps given by them are only theoretical because there is lack of practical experience from the organizations being interviewed. To them this is only an armchair strategy. Presumably, they try to follow the theories to perform the automation, but it may not suit the actual situation of the organization. The advice from the public sector is to set up a pilot project to develop relationship with business and sell the concepts to them. Also, a pilot acts as a bridge helping ensure the product can more easily become part of business as usual (BAU) after the project is finished. A pilot project is the best way to build good knowledge on the use and also a way to show the business unit the results. Mathur listed 4 advantages of pilot project: (1) An opportunity to validate product against customer expectations; (2) Minimal cost of failure; (3) Setting expectations with customer; (4) Eliminate production risks (2012, the advantages are tough to ignore section, para. 1, 2, 3, 4).

In this section, we would like to refer back to literature review (CSF for implementation) with Bret's seven special notes of considerations and challenges. It would be more accurate to say that these notes imply some risks of implementation of automation, than processes of implementing automation. For an organization that using test automation, understanding the potential risks is more important than blindly following.

First, there is financial risk. A legitimate automation tool needs huge funds. Therefore, we need to estimate the cost of tool and the cost that may be spent on adjusting the organization structure due to automation.

Second, the analysis of which IT systems automated testing can be applied to. This analysis helps the organization identify which product's functions can be tested automatically. They often include functional test automation, performance automation and white box automation. For example, some organizations develop their own personal edition software so functional testing is only needed. 
Third, as previously noted, test automation is not everything. Instead, it needs to be coordinated with manual testing effectively. Unreasonable planning could cause the wasted effort.

Fourth, estimation of time. We may need to estimate cycle of implementation of test automation, in order to avoid waste of time and reduce unnecessary consumption of personnel, funds and resources.

Fifth, workflow change. When testing team implements automation, testing or development processes will change less or more. If the change is not well managed, people may complain.

Sixth, personal training and change. Enough staff need to have a solid grasp of knowledge of the software to ensure if there is change of staff the organization as whole will not lose that information and others can be trained.

From the perspective of risk management, risk analysis and corresponding planning for automation should (must) be done during the initial planning phase of project. Ideally, it also should be revised from time to time on a regular basis by relevant people before the project kicks off. The rapid change of Information Technology has made technology transition a necessity rather than an option. Rapid changes in software and hardware have introduced new questions that need to be addressed by organizations making large investments in technologies: How much risk is involved in adopting a technology? (Valerdi \& Kohl, 2004, p. 1). The risks relative to test automation are not only limited to the ones we discussed above. In fact, estimation of risk varies in terms of culture, background, process and budget. The organization still needs to continuously explore it, in order to reduce the risks to the minimum. In this research, analysis against the cost from the potential risks are not covered. However, it can be discussed in the future as a supplementary to an analysis of ROI, which can make the organization's investment more accurate. 


\section{Chapter 5: Comparisons between private and public sectors}

The purpose of this section is to:

1. Summarize all different views for automated testing between private and public sectors. These differences may help organization in identifying the particular concerns when they are choosing or planning to choose automation;

2. Compare with additional literature to figure out discrepancies.

\begin{tabular}{|c|c|c|}
\hline & Private Sector & Public Sector \\
\hline Change window & $\begin{array}{l}\text { Happens quite often to cater for customer's } \\
\text { expectations. }\end{array}$ & $\begin{array}{l}\text { It's hard to change because there are so many approvals } \\
\text { required. }\end{array}$ \\
\hline Tool selection & $\begin{array}{ll}\text { - } & \text { Fits with their own system } \\
\text { - } & \text { Budget } \\
\text { - } & \text { No geographic requirement }\end{array}$ & $\begin{array}{ll}\text { - } & \text { Fits with their own system } \\
\text { - } & \text { Budget } \\
\text { - } & \text { Security - Tool cannot be hosted outside New } \\
& \text { Zealand }\end{array}$ \\
\hline Employee views of new software & More accepting & People are more resistant \\
\hline Purpose & Profit driven & Focus more on service level, with less budget \\
\hline Political factor & N/A & $\begin{array}{l}\text { There is lot of bureaucracy to get approval to } \\
\text { do the stuff }\end{array}$ \\
\hline Security & $\begin{array}{l}\text { Important for privacy and competitive } \\
\text { reasons }\end{array}$ & $\begin{array}{l}\text { For the good of the public. Very } \\
\text { serious because the data is not for us }\end{array}$ \\
\hline
\end{tabular}




\begin{tabular}{|c|c|c|}
\hline & & and it belongs to citizen within New Zealand \\
\hline \multicolumn{3}{|l|}{ Holvorsen et al., 2005, p. 26 - 29} \\
\hline Organising Principles & Pursuit of profit, of stability or of growth of revenues. & Enactment of public policies \\
\hline Organizational Structures & Forms of many sizes, with options for new entrants. & Complex system of organizations with various tasks. \\
\hline Performance Metrics & Return on Investment & Multiple performance indicators and targets \\
\hline Management Issues & $\begin{array}{l}\text { Some managers have considerable autonomy, others } \\
\text { constrained by shareholders, corporate governance, or } \\
\text { financial stringency. Successful managers liable to be } \\
\text { rewarded with substantial material benefits and } \\
\text { promotion. }\end{array}$ & $\begin{array}{l}\text { While there are efforts to emulate private sector } \\
\text { management practice, managers are typically under } \\
\text { high levels of political scrutiny. Successful managers } \\
\text { likely to receive lower material benefits than } \\
\text { comparable private sector managers. }\end{array}$ \\
\hline Relations with End-Users & $\begin{array}{l}\text { Markets may be consumer or industrial ones, and firms } \\
\text { vary in the intimacy of their links with the end-users of } \\
\text { their products, but typically market feedback provides } \\
\text { the verdict on innovation. }\end{array}$ & $\begin{array}{l}\text { End-users are the general public, traditionally seen as } \\
\text { citizens, though recently there have been efforts to } \\
\text { introduce market-type principles and move to see them } \\
\text { as customers or consumers. }\end{array}$ \\
\hline Supply Chains & $\begin{array}{l}\text { Most firms are parts of one or more supply chains, with } \\
\text { larger firms tending to organise these chains. }\end{array}$ & $\begin{array}{l}\text { Public sector is typically dependent on private suppliers } \\
\text { for much of its equipment, and is a very important } \\
\text { market for many firms. }\end{array}$ \\
\hline Employees & $\begin{array}{l}\text { Nature of workforce varies considerably, and relations } \\
\text { between employees and management range from } \\
\text { fractious to harmonious. Efforts are made in some firms } \\
\text { to instil company loyalty and/or a customer-centric } \\
\text { approach, but employee motivations are often mainly } \\
\text { economic ones of securing a reasonable income. }\end{array}$ & $\begin{array}{l}\text { Public sector employees are typically highly unionised } \\
\text { (economists and social scientists in the central } \\
\text { administration and health- and social professionals as } \\
\text { nurses, social workers, child-care workers, teachers etc. } \\
\text { in the public services). Many are also professional } \\
\text { workers organised through professional associations. } \\
\text { While usual concerns about status and salary are } \\
\text { experienced, many workers enter public service with } \\
\text { idealistic motivations. }\end{array}$ \\
\hline Source of Knowledge & $\begin{array}{l}\text { Companies have considerable flexibility in sourcing } \\
\text { innovation related information from consultants, trade } \\
\text { associations, and public sector researchers, but many } \\
\text { smaller firms have limited resources to do so. }\end{array}$ & $\begin{array}{l}\text { Despite large resources, parts of the public sector may } \\
\text { be constrained from using private sources of knowledge } \\
\text { (other than those of suppliers). Public sector sources of } \\
\text { knowledge (e.g. Universities) may be highly oriented to } \\
\text { other parts of the public sector. }\end{array}$ \\
\hline Time Horizon & $\begin{array}{l}\text { Short-term in many sectors, though utilities and } \\
\text { infrastructural services may have very long horizons. }\end{array}$ & $\begin{array}{l}\text { Often long-term (this means that responsible decision- } \\
\text { makers may have moved on by the time that results are } \\
\text { achieved) though many decisions do have shorter } \\
\text { horizons. }\end{array}$ \\
\hline
\end{tabular}

Page 40 of 60 


\section{Table 4: Comparisons between private and public sector}

Through the comparison between private and public sectors, some concerns can be categorized into:

- The differences of values create different management goals: The public sector always faces many ethical dilemmas of public interest, while the private sector is generally treated to be the pursuit of profit. A public sector provides governmental services and funded by taxpayer, which determines the behaviour of the staff are responsible for the public interest. Holvorsen et al. stated that rather than pursuing profits, the public sector are implementing policies that are usually presented as aiming to benefit society as a whole, not least by providing basic services for citizens that private market provision is liable to fail to provide efficiently or equitably (2005, p. 23).

- The differences of behaviour orientation: In the public sector, workers are restricted by more rules and regulations. They focus more on code of conduct and public good than pursuing the maximum profit.

- The difference of employee's qualification requirement: In the private sector, the employer requires employees have the necessary professional ability in the first place. However, the requirement of moral quality seems to be ignored.

The three points above are of the essence of the difference between the private and public sector. Combined with the responses from group discussion, recognizing these differences will benefit to distinguish the private and public behaviour and also search for effective methodology for adoption of innovation. 


\section{Chapter 6: Conclusions \& Recommendations}

In this study, two organizations presented their basic understanding of the automated testing in terms of its definition and expectation of benefits. During the group discussions, some different views were found and helped us re-cognize the automated testing with two additional thoughts including "where can be covered by automation?" and "what are preconditions for automated testing". The former thought breaks the myth of test automation being superior and shows that the automation is not everything. Instead, it provided a broader view about the scope of application of automation. In terms of the responses from all participants, the major themes were: (1) Test data preparation: Preparing the test data requires people involved, such as identifying the location and judging the accuracy of the data; (2) Repetitive task: Automation is good for repetitive tasks, but the module needs to be kept unchanged; (3) System Integration Testing (SIT): We may need to think about carefully about whether the automation suits SIT, because the requirements of the software/the system knowledge is relatively high; (4) Functional or non-functional testing: Whether functional or non-functional testing, as long as it is within the range of testing user ability, the automation tests should be used with caution. The latter thought suggests three preconditions to be considered before implementing the automation: (1) Communication issue: When automation is implemented, we have to make sure that relative staff is available to be communicated at each of work link. Also, other resources are free to be contacted; (2) Team balance: The proportion of permanent and contract role should be balanced within the team, in order to provide an environment where knowledge is better managed and transferred; (3) Type of work: An assessment of what type of work (project or BAU) needs to be automated is necessary.

In the "key considerations" section of this study, we found three key factors that may affect the test automation from the perspective of human nature including people resistance, working process and training people. Based on the characteristics of the automation, people resistance was firstly analysed to see whether adoption of automation could be blocked because employee is worried of being redundant. The responses from the participants were positive and implied that people resistance for automation could be considered from other perspectives. In this study, the discussion for people resistance was very limited due to lack 
of practice in implementing automation for a real project. Second, how the automation can be effectively combined with the current working process is an important link to consider. Third, getting people trained is an effective way to make people accept the new software faster. Also, Roger's DOI theory was referenced to assist the organization in expanding the knowledge within the team. During the discussion of considerations, some special concerns were found from a managerial perspective between reviewed literature and participant's recomposes. (1) Cost-benefit analysis: There was a lack of knowledge/understanding of how best to calculate, measure \& model ROI; (2) Management support: Identifying the collaboration of business and information technology as a key factor, management involvement and building relations with other business units (buy-in) were advised; (3) Tool selection: Selecting suitable tools based on the actual situation within the organization was suggested.

In terms of reviewed literature for CSF, we got similar responses from the participants. In the meantime, some potential risks were dig out for implementing the automation that may happen within the organization. At the end of this study, comparisons between private and public sector were made to analyse different behaviours from different background for adoption of technology.

For automated testing, it is a long-term process, which cannot be finished in one day. The development of new technology needs a lot of investment into human and resources. Recommendations are listed below:

- Crucially, executives must agree that it is important to introduce the automation and champion its introduction, rather than wasting money. It can be understood that there is no any automation experience in practice within the interviewed organizations, but at least the automation, as a development trend in the field of testing, should be recognized and accepted.

- Before implementing the automation, assessment and analysis should be well organized by experts internally or externally, which include current working process, change management, tool selection and risk evaluation. If possible, they should be calculated with the fixed costs of automation. 
- Considering commercial software is relatively expensive, we may think about open source testing tools. It is not only cheaper, but also allows users to know more characteristics of the test automation. Presumably, if the tools in the market cannot meet business requirements, self-developing the tool can be considered. However, it is not recommended to the organization that have started using automation.

- In terms of tool selection, we need to also consider its integration, expandability and compatibility. This is because we often need to combine testing process, requirement management, defect management and configuration management together.

- Before the full implementation of automated testing, pilot project with automation is recommended. Some benefits may be brought: (1) It can introduce automation to a smaller part of the organization to understand its impact on potential business process and staff; (2) The drawbacks from the pilot project can be summarized as lessons learnt and try to avoid in the later work; (3) It shows organization a proof of concept to demonstrate its feasibility. For example, return of investment is always one of the most concerns for the organization. To estimate the ROI of automation, we need to build up a model based on the actual situation within the organization. Aside from fixed costs we mentioned previously, some factors affecting the cost of automation also need to be analysed. As a matter of fact, these potential factors need to be dig out during the pilot project. The more detailed analysis we have, more accurate the calculation is.

- A future study of automated testing for two organizations could be considered from three perspectives: (1) Cost: The cost of the new technology has always been the first consideration. Therefore, how to combine the results of the pilot project to model a return of investment is worth learning; (2) Framework: To realise the true automated testing, it moves beyond the understanding of testing toolset and testing script. Building a framework to ensure future implementation of automated testing more smoothly and orderly is ultimate goal. The framework should have characteristics of reusability, maintainability, stability, speed of writing script, accuracy of the outcomes and automated execution; (3) Knowledge management: Knowledge as organizational capital, has become the first strategic resource in economic development. Based on the mobility of employees within the organization, a study should be further explored on the transformation of the knowledge and behaviour from the perspective of interaction between human and information. This suggested 
study is not only used for automated testing, but also for whole point of view aiming to knowledge management. 


\section{References}

Argyres, N.S., \& Silverman, B.S. (2004). R\&D, organization structure, and the development of corporate technological knowledge. Strategic management Journal, 25, 929-958.

Attar, G.A., \& Sweis, R.J. (2010). The relationship between information technology adoption and job satisfaction in contracting companies in Jordan. Journal of information technology in construction (ITcon), Vol.15, 44-63.

Basu, V., Hartono, E., Lederer, A.L., \& Sethi, V. (2002). The impact of organizational commitment, senior management involvement, and team involvement on strategic information systems planning. Information \& Management, 39, 513-524.

Berner, S., Weber, R., \& Keller, R. K. (2005). Observations and lesson learned from automated testing. Missouri, USA.

Blackburn, M., Busser, R., \& Nauman, A. (2004). Why model-based test automation is different and what you should know to get started. Retrieved from http://team4model.googlecode.com/svn/trunk/resources/paper/MBT\%20Introduction/material /Why\%20Model-

Based\%20Testing\%20is\%20Different $\% 20$ and $\% 20$ What $\% 20$ You $\% 20$ Should $\% 20$ Know $\% 20 \mathrm{t}$ o\%20Get\%20Started.pdf

Borland. (2012). How to successfully automate the functional testing process. Retrieved from https://www.borland.com/_images/Silk-Test_WP_How-to-successfully-automate-thefunctional-testing-process tcm32-205735.pdf

Damm, L.O., Lundberg, L., \& Olsson, D. (2005). Introducing test automation and test-driven development: An experience report. Electronic notes in theoretical computer science, 116, 315 .

Dance, J. (2008). 3 pillars every organization/team must address for effective innovation. Retrieved from http://www.freshconsulting.com/3-pillars-every-organizationteam-mustaddress-for-effective-innovation/

Dascal, M., \& Dror, I.E. (2005). The impact of cognitive technologies. Pragmatics \& Cognition, 13(3), 451-457. 
Davis, F. D. (1989). Perceived usefulness, perceived ease of use, and user acceptance of information technology. MIS Quarterly, 13 (3), 319-340.

Dustin, E., Rashka, J., \& Paul, J. (1999). Automated Software Testing: Introduction, Management, and Performance. New York: Addison-Wesley.

Fecko, M.A., \& Lott, C.M. (2002). Lessons learned from automation tests for an operations support system. Software practice and experience. New Jersey: John Wiley \& Sons.

Fewster, M., \& Graham, D. (1999). Software test automation: Effective use of test execution tools. New York: ACM Press.

Finsterwalder, M. (2001). Automating acceptance tests for GUI applications in an extreme programming environment. Retrieved from http://cf.agilealliance.org/articles/system/article/file/889/file.pdf

Flatworld Solutions. (2014). The advantages and disadvantages of outsourcing. Retrieved from http://www.flatworldsolutions.com/articles/advantages-disadvantages-outsourcing.php

Frost, S. (2014). The Importance of Training \& Development in the Workplace. Retrieved from http://smallbusiness.chron.com/importance-training-development-workplace-10321.html

Halvorsen, T., Hauknes, J., Miles, I., \& Roste, R. (2005). On the differences between public and private sector innovation. Retrieved from http://unpan1.un.org/intradoc/groups/public/documents/apcity/unpan046809.pdf

Hayes, L. G. (2004). The Automated Testing Handbook. Retrieved from http://www.softwaretestpro.com/itemassets/4772/automatedtestinghandbook.pdf

Hoffman, D. (1999). Cost benefits analysis of test automation. Retrieved from http://www.softwarequalitymethods.com/papers/star99\%20model\%20paper.pdf

Hoffman, D. (1999). Test automation architectures: Planning for test automation. Software Quality Methods, LLC. 
Kaner, C. (1997). Improving the maintainability of automated test suites. Retrieved from http://www.kaner.com/pdfs/autosqa.pdf

Kelly, M. (2011) The ROI of test automation. Retrieved from http://www.sqetraining.com/sites/default/files/articles/XDD8502filelistfilename1_0.pdf

Kettinger, W. J., Zhang, C., \& Marchand, D. A. (2011). CIO and business executive leadership approaches to establishing company - wide information orientation. MIS Quarterly Executive, 10 (4), 157-174.

Keyes-Pearce, S. (1997). Linkage between business plans and information system strategies across hospital organisational networks. PACIS Proceedings, 635-640.

Lindh, C. (2006). Business Relationships and Integration of Information Technology. Retrieved from http://www.diva-portal.org/smash/get/diva2:120516/FULLTEXT01.pdf

Mathur, A. (2012). The Managed Pilot Project: A Wise Product Owner's Choice for Success. Retrieved from http://www.brighthubpm.com/monitoring-projects/127822-the-managedpilot-project-a-wise-product-owners-choice-for-success/

Pettichord, B. (2001). Seven steps to test automation success. Retrieved from http://www.testpoint.com.au/attachments/093_Seven\%20Steps\%20to\%20Test\%20Automatio $\underline{\mathrm{n} \% 20 \text { Success.pdf }}$

Pocatilu, P. (2002). Automated software testing process. Retrieved from http://www.economyinformatics.ase.ro/content/EN2/pocatilu.pdf

Poston, R. M., \& Sexton, M. P. (1992). Evaluating and Selecting Testing Tools. Retrieved from

http://www.it.iitb.ac.in/ palwencha/mtp_third/Prashant\%20Palwencha/lic/pap1412/evaluatin g\%20and\%20selecting\%20testing\%20tools.pdf

PricewaterhouseCoopers. (2012). How to drive innovation and business growth: Leveraging emerging technology for sustainable growth. Retrieved from http://www.pwc.com/en_US/us/supply-chain-management/assets/pwc-oracle-innovationwhite-paper.pdf 
Rafi, D. M., Moses, K. R. K., \& Petersen, K. (2012). Benefit and limitations of automated software testing: Systematic literature review and practitioner survey. Retrieved from http://www.soberit.hut.fi/mmantyla/ast_2012_bare_conf.pdf

Rick, T. (2011). Top 12 reasons why people resist change. Retrieved from http://www.torbenrick.eu/blog/change-management/12-reasons-why-people-resist-change/

Rogers, E. M. (1962). Diffusion of innovations. Glencoe: Free Press. ISBN 0-612-62843-4

Thummalapenta, S., Sinha, S., Mukherjee, D., \& Chandra, S. (2011). Automating test automation. Retrieved from http://researcher.watson.ibm.com/researcher/files/insaurabhsinha/ata-techrep-RI11014.pdf

Tost, A. (2010). Comment lines: Then challenges of introducing new technology. Retrieved from

http://www.ibm.com/developerworks/websphere/techjournal/1010_col_tost/1010_col_tostpdf.pdf

University of Melbourne. (2010). Case studies: Research methods. Retrieved from http://sydney.edu.au/business/_data/assets/pdf_file/0020/90362/Txt_casestudy_research.pdf

Valerdi, R., \& Kohl, R. J. (2004). An Approach to Technology Risk Management. Retrieved from https://esd.mit.edu/symposium/pdfs/papers/valerdi.pdf

Venkatesh, V., Morris, M. G., Davis, G.B., \& Davis, F.D. (2003). User acceptance of information technology: Toward a unified view. MIS Quarterly, 27 (3), 425-478.

Walton, R.E., \& McKersie, R.B. (1988). Managing new technology and labor relations: An opportunity for mutual influence. Retrieved from http://dspace.mit.edu/bitstream/handle/1721.1/2226/SWP-2096-21344628.pdf

Worksoft. (2011). Risk-based test automation from a business process perspective. Retrieved from https://www.worksoft.com/files/resources/Worksoft-Paper-Risk-Based-TestAutomation-From-A-Business-Process-Perspective.pdf 


\section{Appendix 1 - Focus Group Discussion Questions}

General questions will be asked to everyone for overviewing the topic. Specific questions are also available to each one of them, but will depend on their own role. Sample focus group questions are shown below, but are not limited to:

\section{Focus Group Questions -}

- Can you each please describe your position within the organization?

- How would you describe the current status of manual testing?

- What issues or problems are experienced with manual testing?

- What is your opinion of automated testing as the best solution against problems with manual testing? Explain?

- In terms of the current situation within your work situation, what investment would be needed to implement automated testing? What returns would you expect from the investment?

- In your opinion, what factors need to be considered before the implementation of automated testing?

- In your opinion, how would a process of automated testing be implemented?

- If automated testing was implemented, where should it be applied?

- If automated testing applies, how might this affect your role?

- Would automated testing in public sector organisations differ from that in the private sector - if any? Please explain. 


\section{Appendix 2 - Discussions Matrix}

All names provided in the matrix table are not actual name in terms of conditions from Participant Consent Form.

\begin{tabular}{|c|c|c|c|c|c|c|}
\hline Participant & $\begin{array}{l}\text { Participant } 1 \\
\text { Helen - Test } \\
\text { Lead }\end{array}$ & $\begin{array}{l}\text { Participant } 2 \\
\text { Lisa - Senior TA }\end{array}$ & $\begin{array}{l}\text { Participant } 3 \\
\text { Coy - manual } \\
\text { test analyst }\end{array}$ & $\begin{array}{l}\text { Participant } 4 \\
\text { \& } 5 \\
\text { Noelle \& Lily }\end{array}$ & $\begin{array}{l}\text { Participant } 6 \\
\text { Susan - Team } \\
\text { manager }\end{array}$ & $\begin{array}{l}\text { Participant } 7 \text { \& } 8 \\
\text { Allan \& Andrew }\end{array}$ \\
\hline Q 1 & $\begin{array}{l}\text { Test lead for data } \\
\text { migration project } \\
\text { and there are } 5 \\
\text { members within the } \\
\text { team }\end{array}$ & $\begin{array}{l}\text { Lisa is employed as a } \\
\text { senior test analyst, for a } \\
\text { specific project - data } \\
\text { migration from legacy to } \\
\text { new system. Basically, } \\
\text { she is doing data } \\
\text { migration testing from } \\
\text { source to target. }\end{array}$ & $\begin{array}{l}\text { I am currently a } \\
\text { manual test analyst } \\
\text { for } x x x \text { project at } \\
x x x\end{array}$ & $\begin{array}{l}\text { We are contract } \\
\text { test analyst from } \\
\text { outsourcing } \\
\text { company }\end{array}$ & $\begin{array}{l}\text { Team manager role in the } \\
\text { testing team. Responsible } \\
\text { on managing the whole } \\
\text { process, coordinating and } \\
\text { reporting. }\end{array}$ & $\begin{array}{l}\text { Allan - Senior developer and take more } \\
\text { responsibility on team lead } \\
\text { Andrew - Team manager and responsible on } \\
\text { looking for technical tester, resourcing, task } \\
\text { allocation and NPE. }\end{array}$ \\
\hline Q 2 & $\begin{array}{l}\text { - Project } \\
\text { BAU } \\
\text { There is no } \\
\text { automation (like } \\
\text { automation script or } \\
\text { automation tool) in } \\
\text { the place. }\end{array}$ & $\begin{array}{l}\text { Testing is repetitive as } \\
\text { we are repeating cycle of } \\
\text { testing by extracting new } \\
\text { sources and putting into } \\
\text { the staging table and } \\
\text { loading into the new } \\
\text { database. } \\
\text { System testing - source } \\
\text { to target. Regression is } \\
\text { not involved until front } \\
\text { to end release. }\end{array}$ & $\begin{array}{l}\text { doing } \\
\text { comparison testing } \\
\text { using SQL or SQL } \\
\text { tools }\end{array}$ & Data migration & $\begin{array}{l}\text { Very manual. However, } \\
\text { not very well because there } \\
\text { is no management and } \\
\text { process around it. }\end{array}$ & $\begin{array}{l}\text { All good from developer's perspective. To } \\
\text { test the code once it is finished. } \\
\text { Normal process: involved in the beginning } \\
\text { of the project }->\text { test plan }->\text { detailed } \\
\text { requirements }->\text { test analysis }->\text { design test } \\
\text { cases } \\
\text { High level documentation }\end{array}$ \\
\hline
\end{tabular}




\begin{tabular}{|c|c|c|c|c|c|c|}
\hline Q 3 & $\begin{array}{l}\text { - } \text { different } \\
\text { people and } \\
\text { different } \\
\text { vendor are } \\
\text { doing the } \\
\text { different } \\
\text { works } \\
\text { Test data } \\
\text { need to be } \\
\text { prepared } \\
\text { but don't } \\
\text { know } \\
\text { where is } \\
\text { it? } \\
\text { Categories } \\
\text { keep } \\
\text { changing } \\
\text { HPQC } \\
\text { access } \\
\text { issue }\end{array}$ & 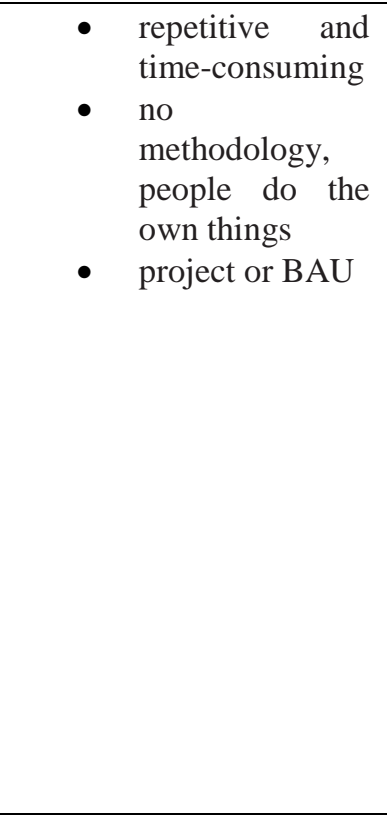 & $\begin{array}{l}\text { Timing things, } \\
\text { which is ready for } \\
\text { testing or not. It is } \\
\text { not a problem from } \\
\text { testing itself }\end{array}$ & $\begin{array}{ll}- & \text { Inconsist } \\
\text { ent } \\
\text { mapping } \\
\text { documen } \\
\mathrm{t} \\
\text { - } \\
\text { Commun } \\
\text { ication } \\
\text { issue due } \\
\text { to the } \\
\text { location } \\
\text { - No } \\
\text { proper } \\
\text { training } \\
-\quad \text { less } \\
\text { permane } \\
\text { nt staff }\end{array}$ & $\begin{array}{l}\text { The process is not well- } \\
\text { known and well- } \\
\text { established within the } \\
\text { company }\end{array}$ & $\begin{array}{l}\text { - } \quad \text { People are not perfect } \\
\text { - } \quad \text { time-based data } \\
\text { - Conflict between project and BAU } \\
\text { - Communication issue between } \\
\text { vendor and organization. }\end{array}$ \\
\hline Q 4 & $\begin{array}{l}\text { Helen doesn't think } \\
\text { that the automated } \\
\text { testing is the best } \\
\text { solution against the } \\
\text { data issue. The } \\
\text { reason is that test } \\
\text { data preparation is } \\
\text { still needed as } \\
\text { manually, whatever } \\
\text { manual or on on } \\
\text { automated testing. }\end{array}$ & $\begin{array}{l}\text { Can be but maintaining } \\
\text { the automation script is } \\
\text { another issue }\end{array}$ & $\begin{array}{l}\text { automated testing is } \\
\text { a great thing for } \\
\text { regression }\end{array}$ & $\begin{array}{l}\text { We don't think } \\
\text { that automated } \\
\text { testing will be a } \\
\text { solution for these } \\
\text { problems. } \\
\text { Sort out the } \\
\text { problems first to } \\
\text { male automation } \\
\text { easy. } \\
\text { - Precondi } \\
\text { tion }\end{array}$ & $\begin{array}{l}\text { It depends on what type of } \\
\text { testing you could use } \\
\text { automation or not. I } \\
\text { haven't use automated } \\
\text { testing before so not } \\
\text { familiar with } \\
\quad \text { - Precondition } \\
\text { Argued point: } \\
\text { Automation should be } \\
\text { driven by process }\end{array}$ & $\begin{array}{l}\text { Allan - } \\
\text { Sort out process first. Automated testing, } \\
\text { from my perspective, would address those } \\
\text { two issue. } \\
\text { Cannot be as some tests are based on time. } \\
\text { Automation can be an enabler of driving } \\
\text { people to prepare the best data. }\end{array}$ \\
\hline
\end{tabular}




\begin{tabular}{|c|c|c|c|c|c|c|}
\hline Q 5 & 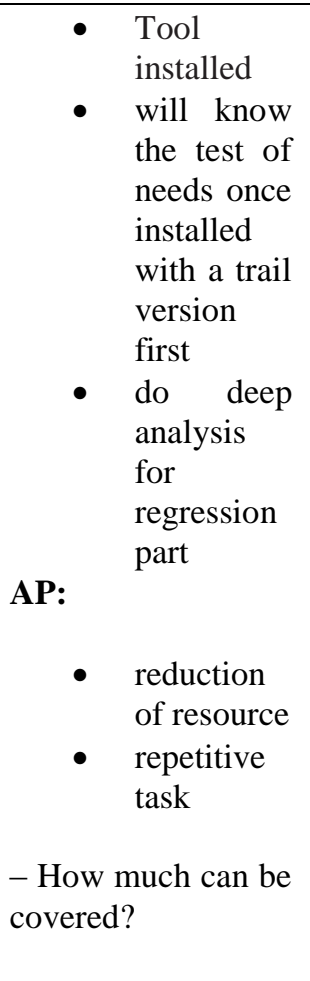 & 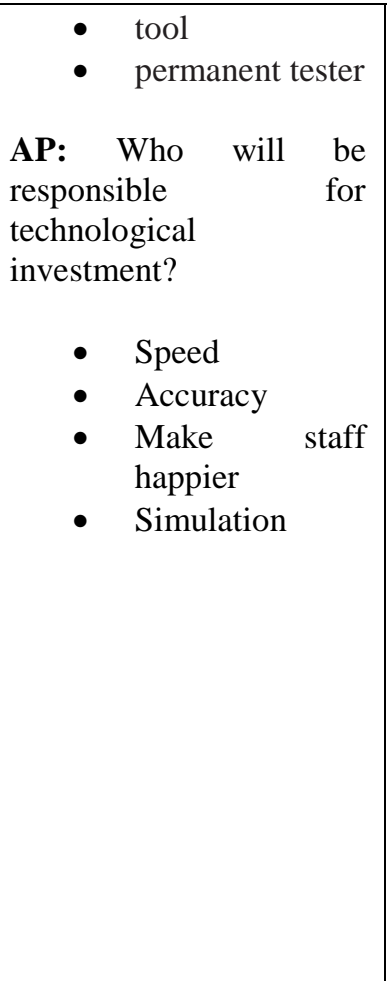 & $\begin{array}{l}\text { N/A } \\
\text { - How much can be } \\
\text { covered? }\end{array}$ & 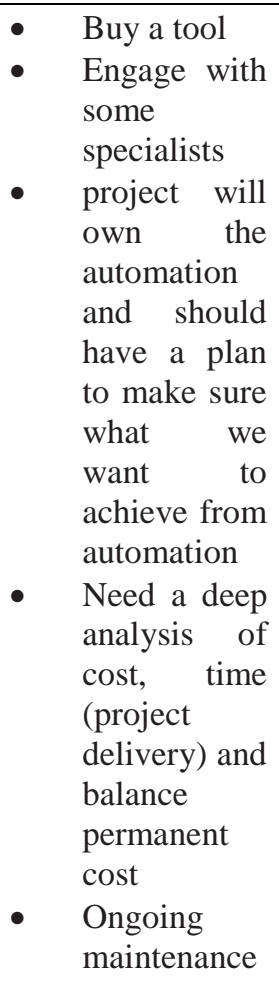 & $\begin{array}{l}\text { - } \text { Save time } \\
\text { - Reports can be } \\
\text { produced } \\
\text { consequently } \\
\text { - Cost reduction - I } \\
\text { suppose that it } \\
\text { might initial } \\
\text { outline and cost } \\
\text { and then they are } \\
\text { going to get } \\
\text { reduction because } \\
\text { all benefits are for } \\
\text { future project. }\end{array}$ & $\begin{array}{l}\text { Allan - } \\
\text { - confidence when we change the } \\
\text { codes } \\
\text { confidence again to make sure that } \\
\text { regressions don't happen } \\
\text { Andrew - } \\
\text { - Test sweets would be faster to run } \\
\text { and more robust } \\
\text { My team is more skilled and } \\
\text { valuable. }\end{array}$ \\
\hline Q 6 & Cost & $\begin{array}{l}\text { Does subject } \\
\text { material allow } \\
\text { for it? Can } \\
\text { something be } \\
\text { tested r in } \\
\text { automated } \\
\text { manner? } \\
\text { I am assuming } \\
\text { that the } \\
\text { organization } \\
\text { buys a tool as a } \\
\text { whole, not just } \\
\text { for technology, }\end{array}$ & $\begin{array}{l}\text { - You need to } \\
\text { look at the tool } \\
\text { you want to } \\
\text { use. Often, } \\
\text { organization } \\
\text { goes down to } \\
\text { track quite } \\
\text { expensive tool } \\
\text { or any free } \\
\text { one. } \\
\text { Budget tray is } \\
\text { huge including } \\
\text { tool, person }\end{array}$ & $\begin{array}{ll}- & \text { Cost-benefit } \\
- & \text { Timing } \\
- & \text { People } \\
& \text { resistance } \\
- & \begin{array}{l}\text { Management } \\
\text { (buy-in) }\end{array}\end{array}$ & $\begin{array}{l}\text { - We need to } \\
\text { actually } \\
\text { determine what } \\
\text { process will be } \\
\text { benefit from } \\
\text { automation. I am } \\
\text { pretty sure that } \\
\text { some processes } \\
\text { we had are easily } \\
\text { to be automated. } \\
\text { But that still } \\
\text { needs to be } \\
\text { worked out and }\end{array}$ & $\begin{array}{ll}\text { - } & \text { Education } \\
\text { - } & \text { Technology } \\
\text { - } & \text { Infrastructure } \\
\text { - } & \text { Environment } \\
\text { We need to keep the changing } & \text { technology needs to be attempted } \\
& \text { by someone in the right level. This } \\
& \text { is good thing and everyone will be } \\
& \text { buy-in to it. } \\
\text { - } & \text { People engaged } \\
\text { - } & \text { Cost }\end{array}$ \\
\hline
\end{tabular}




\begin{tabular}{|c|c|c|c|c|c|c|}
\hline & & $\begin{array}{l}\text { to define pipe } \\
\text { line of works } \\
\text { that come } \\
\text { through because } \\
\text { I think that it is } \\
\text { big investment } \\
\text { to make. } \\
\text { Get permanent } \\
\text { staff trained, } \\
\text { doesn't like that } \\
\text { people get } \\
\text { training and } \\
\text { leave. } \\
\text { People can stay } \\
\text { and pass } \\
\text { information to } \\
\text { others } \\
\text { (knowledge } \\
\text { management). }\end{array}$ & $\begin{array}{l}\text { and person's } \\
\text { time } \\
\text { Keep tool \& } \\
\text { automation } \\
\text { script up-to- } \\
\text { date. If you } \\
\text { make change, } \\
\text { you have to } \\
\text { make sure it } \\
\text { cooperate with } \\
\text { automation } \\
\text { script. } \\
\text { Knowledge } \\
\text { management } \\
\text { licence }\end{array}$ & & $\begin{array}{l}\text { determine how } \\
\text { we do the things } \\
\text { faster and more } \\
\text { efficient in the } \\
\text { future. I think that } \\
\text { it is good } \\
\text { opportunity to } \\
\text { learn and develop } \\
\text { in the } \\
\text { organization. } \\
\text { Team balancing }\end{array}$ & \\
\hline Q 7 & $\begin{array}{ll}\text { - } & \text { People } \\
\text { - } & \text { Preparing } \\
\text { and } \\
\text { analysing } \\
\text { - Plan }\end{array}$ & $\begin{array}{l}\text { - Tool } \\
\text { - Get people, } \\
\text { permanent or } \\
\text { contract } \\
\text { - Analyse to see } \\
\text { if tool fits to the } \\
\text { current business } \\
\text { process } \\
\text { - Train people } \\
\text { and knowledge } \\
\text { transfer } \\
\text { Make task into } \\
\text { two parts, one is } \\
\text { to write script } \\
\text { and other is to } \\
\text { run. }\end{array}$ & 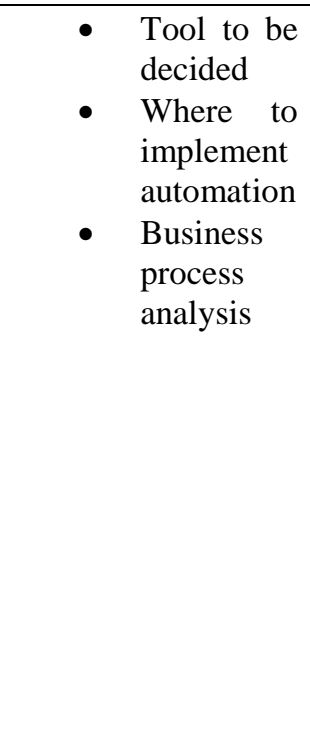 & 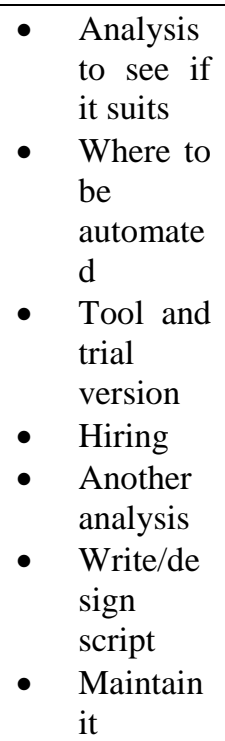 & & $\begin{array}{l}\text { - Pilot } \\
\text { - Automation doesn't fit everything } \\
\text { so if the pilot works then I would } \\
\text { see which parts of product will be } \\
\text { better fit to automation. } \\
\text { - Moving the automation out of our } \\
\text { team. }\end{array}$ \\
\hline
\end{tabular}




\begin{tabular}{|c|c|c|c|c|c|c|}
\hline & & & & $\begin{array}{ll}- & \text { Lessons } \\
& \text { learnt }\end{array}$ & & \\
\hline Q 8 & $\begin{array}{l}\text { - } \begin{array}{l}\text { repetitive } \\
\text { task } \\
\text { against } \\
\text { regression } \\
\text { testing }\end{array} \\
\text { Helen agreed that } \\
\text { automated testing } \\
\text { should be applied to } \\
\text { area where the } \\
\text { modules are kept } \\
\text { unchanged. } \\
\text { Not for } \\
\text { SIT }\end{array}$ & $\begin{array}{l}\text { It should be regression } \\
\text { testing, but still depends } \\
\text { on what you are testing. } \\
\text { Also, the automation } \\
\text { could be used for } \\
\text { functional testing. }\end{array}$ & $\begin{array}{l}\text { Regression and } \\
\text { function testing } \\
\text { Non-functional } \\
\text { - Performance } \\
\text { - Volume }\end{array}$ & $\begin{array}{ll}\text { - } & \text { Function and } \\
\text { process } \\
\text { Repetitive } \\
\text { task } \\
\text { - } \text { Regression } \\
\text { testing } \\
\text { Downstream } \\
\text { testing } \\
\text { UAT would } \\
\text { be not so } \\
\text { good for } \\
\text { automation. } \\
\text { The reason } \\
\text { is it belongs } \\
\text { to non- } \\
\text { functional } \\
\text { and only for } \\
\text { users. They } \\
\text { have to give } \\
\text { their own } \\
\text { opinion so } \\
\text { people are } \\
\text { needed. } \\
\text { Automation } \\
\text { is not for } \\
\text { user ability. }\end{array}$ & $\begin{array}{l}\text { - Repetitive cycle } \\
\text { in terms of } \\
\text { keeping system } \\
\text { up-to-date }\end{array}$ & $\begin{array}{l}\text { Functional and behaviour tests. } \\
\text { non-functional stuff, like performance, load, } \\
\text { and stress }\end{array}$ \\
\hline Q 9 & $\begin{array}{l}\text { - It will not } \\
\text { affect her. } \\
\text { The } \\
\text { automation } \\
\text { is only for } \\
\text { certain of } \\
\text { test scripts }\end{array}$ & $\begin{array}{l}\text { I am contractor and don't } \\
\text { think that it will affect } \\
\text { me. If I were permanent } \\
\text { staff, I am pretty } \\
\text { confident to be involved } \\
\text { in and expected to up } \\
\text { skill, train and learn. }\end{array}$ & $\begin{array}{l}\text { The reality is that I } \\
\text { am contract and } \\
\text { doesn't care } \\
\text { whether automation } \\
\text { does or doesn't } \\
\text { affect me. If I were } \\
\text { permanent staff, I }\end{array}$ & $\begin{array}{l}\text { We don't think } \\
\text { that will affect } \\
\text { that much. They } \\
\text { just need to learn } \\
\text { new stuff. Manual } \\
\text { testing is still } \\
\text { needed. }\end{array}$ & $\begin{array}{l}\text { - Make it way more } \\
\text { efficient. I can } \\
\text { spend my time } \\
\text { doing other things } \\
\text { I am not afraid } \\
\text { about as there are } \\
\text { always so many }\end{array}$ & 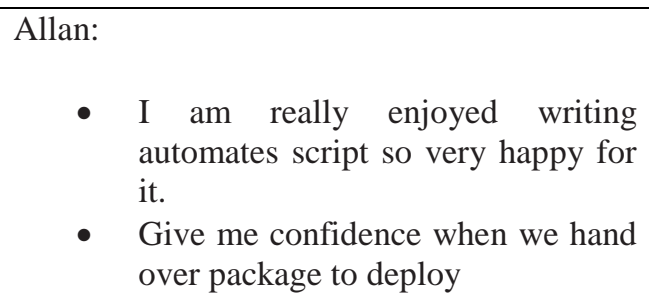 \\
\hline
\end{tabular}




\begin{tabular}{|c|c|c|c|c|c|c|}
\hline & $\begin{array}{l}\text { - } \text { More } \\
\text { responsibil } \\
\text { ity on } \\
\text { reporting } \\
\text { and always } \\
\text { requires } \\
\text { manual } \\
\text { interaction } \\
\text { as error } \\
\text { comes }\end{array}$ & & $\begin{array}{l}\text { could learn new } \\
\text { skills. The manual } \\
\text { testing is still } \\
\text { needed. } \\
\text { Argued point: } \\
\text { whether or not } \\
\text { automation will } \\
\text { replace manual } \\
\text { testing in the next } \\
\text { 5-10 years }\end{array}$ & & $\begin{array}{l}\text { things to do } \\
\text { Obviously, it save } \\
\text { time for us but } \\
\text { something could } \\
\text { be coming } \\
\text { Interests staff - } \\
\text { we can do the } \\
\text { things in better } \\
\text { way, that's good } \\
\text { I am not scared } \\
\text { that the } \\
\text { automation could } \\
\text { replace me. The } \\
\text { world is changing } \\
\text { constantly and } \\
\text { you just need to } \\
\text { adapt it and learn } \\
\text { new skills - Open } \\
\text { to change }\end{array}$ & $\begin{array}{l}\text { Andrew: } \\
\text { - How I will recruit people. I will } \\
\text { need to look for people with } \\
\text { technical skills or technical } \\
\text { capability } \\
\text { - How I will train people } \\
\text { - How I assign people. We need } \\
\text { people with another skill set to fit } \\
\text { project. This belongs to resource } \\
\text { assignment. } \\
\text { And also mean that I am given a bit } \\
\text { more technical stuff, which I would } \\
\text { like, because I am leading a } \\
\text { technical team. Overall, just make } \\
\text { me re-focus how we manage } \\
\text { people and how we lead them. }\end{array}$ \\
\hline Q 10 & $\begin{array}{l}\text { In private sector, } \\
\text { the new changes } \\
\text { could come for } \\
\text { every six months } \\
\text { while it is hardly } \\
\text { changed in public } \\
\text { sector because there } \\
\text { are so many } \\
\text { approvals required } \\
\text { and take ages. }\end{array}$ & 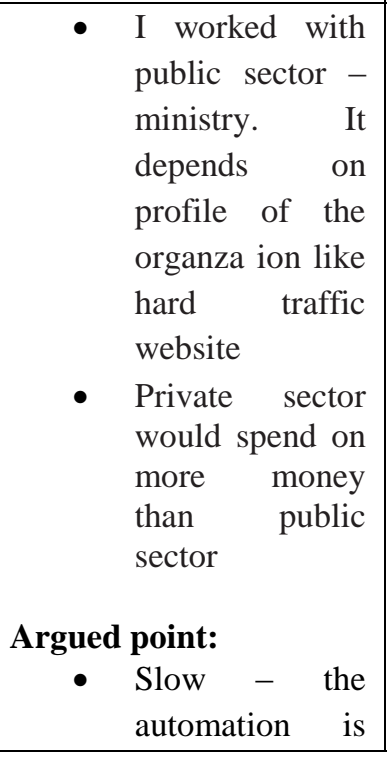 & $\begin{array}{l}\text { - } \begin{array}{l}\text { Tool selection } \\
\text { (depends on }\end{array} \\
\text { different } \\
\text { system ) } \\
\text { Budget, but no } \\
\text { point to } \\
\text { compare } \\
\text { between } \\
\text { private and } \\
\text { public sector. } \\
\text { For some } \\
\text { governments, } \\
\text { there are rich } \\
\text { and can spend } \\
\text { money on big } \\
\text { investment. } \\
\end{array}$ & 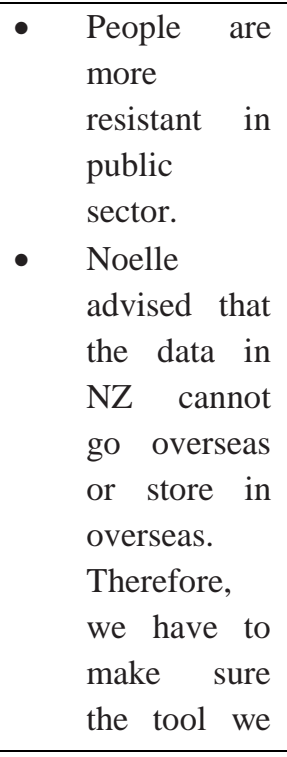 & $\begin{array}{l}\text { I haven't worked with } \\
\text { public sector and only } \\
\text { been with private one. The } \\
\text { only thing I though is } \\
\text { confidential stuff. } \\
\text { The private sector may } \\
\text { have more money to play } \\
\text { with. However, that will be } \\
\text { an overpaid system if thing } \\
\text { goes wrong. }\end{array}$ & $\begin{array}{l}\text { - Public sector is not driven by } \\
\text { profit, but better service. We } \\
\text { get vote for allocating budget. } \\
\text { Government is constrain to } \\
\text { budget because we still need to } \\
\text { think about from service level } \\
\text { even there is big profit with } \\
\text { less budget. } \\
\text { - Different between different } \\
\text { governments. Some of them } \\
\text { put more budget on front line } \\
\text { system while others put in on } \\
\text { back office. } \\
\text { There are lots of bureaucracy } \\
\text { to get approval to do the stuff. } \\
\text { That's less freedom because }\end{array}$ \\
\hline
\end{tabular}

\section{Page 56 of 60}




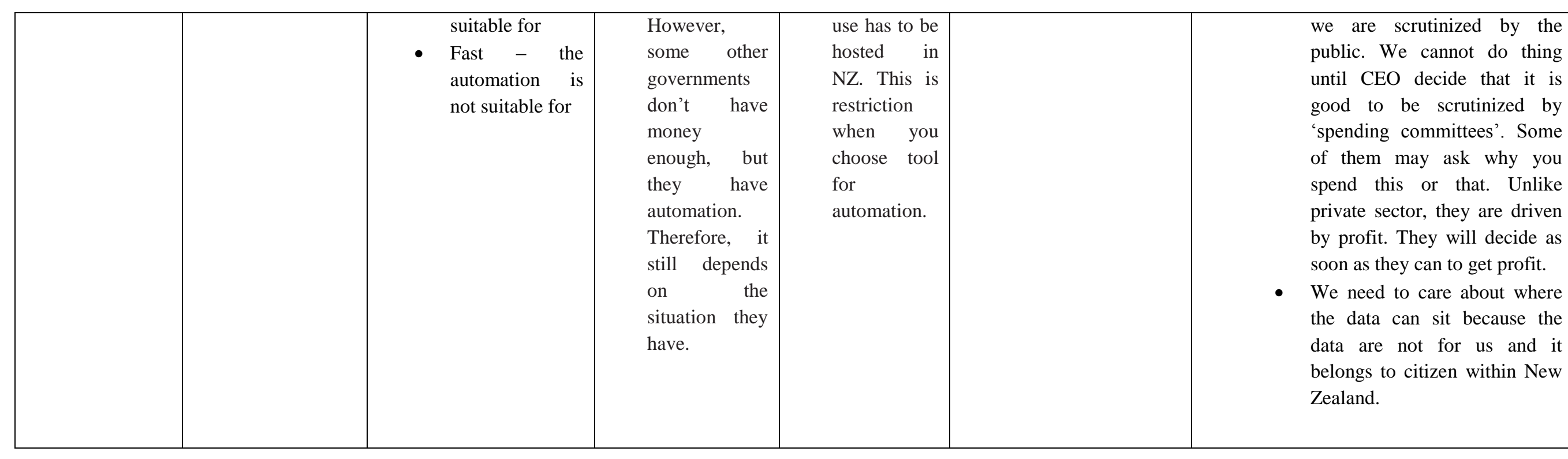

